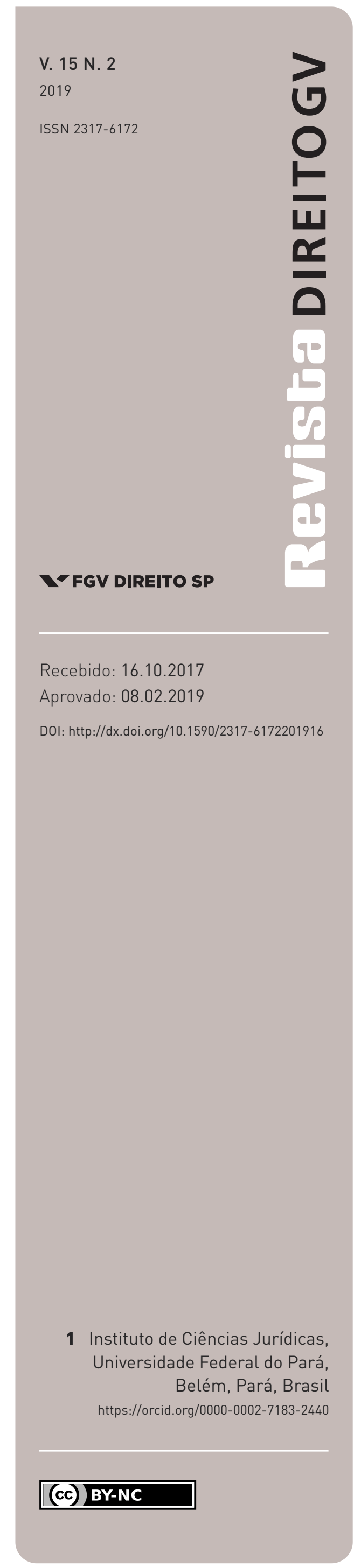

\section{O Estado de Coisas Inconstitucional na ADPF 347 e a sedução do Direito: o impacto da medida cautelar e a resposta dos poderes políticos}

THE STATE OF UNCONSTITUTIONAL AFFAIRS IN THE ADPF 347 AND THE LAW'S ALLURE: THE IMPACT OF THE INTERIM ORDER AND THE POLITICAL POWERS' RESPONSES

\section{Breno Baía Magalhães ${ }^{1}$}

\section{Resumo}

Este artigo pretende analisar o Estado de Coisas Inconstitucional a partir da avaliação dos impactos nos três poderes da República da medida cautelar deferida pelo Supremo Tribunal Federal (STF) e da possibilidade de mudanças sociais a partir dela. Ao tratar da decisão do STF na ADPF 347 como uma decisão que cria caminhos políticos a serem percorridos pelos agentes envolvidos, no caso, os Poderes Executivo, Legislativo e Judiciário, busca-se avaliar a viabilidade das respostas apresentadas no sentido de alcançarem, ou não, as exigências formuladas pela decisão judicial. Os dados coletados no âmbito dos poderes foram contrastados com os objetivos das medidas cautelares e com as justificativas do Estado de Coisas Inconstitucional. Em seguida, argumenta-se a impossibilidade de mudanças na situação fática apontada por meio das categorias jurídicas, com base nas teses de Gerald Rosenberg sobre quando ocorrem mudanças sociais por intermédio do Direito. 0 estudo conclui que as medidas cautelares deferidas não são efetivas, pois os poderes apresentaram respostas que seguem a mesma natureza das políticas tradicionalmente desenvolvidas no Brasil, e que é pouco provável uma mudança social por meio da declaração do Estado de Coisas Inconstitucional.

\section{Palavras-chave}

Estado de Coisas Inconstitucional (ECI); Supremo Tribunal Federal (STF); medida cautelar; mudança social.

\begin{abstract}
This article intends to analyze the State of Unconstitutional Affairs from the evaluation of the impacts of the interim order granted by the STF in the three branches of the Republic and the possibility of social changes from it. Dealing with the decision of the STF in ADPF 347 as a decision that creates political paths to be covered by the involved agents, in this case, the Executive, Legislative and Judicial powers, it seeks to evaluate the feasibility of the answers presented in order to reach, or not, the requirements formulated by the judicial decision. The data collected in the scope of the powers were contrasted with the objectives of the interim orders and with the justifications of the State of Unconstitutional Affairs. Next, the article argues for the impossibility of changes in the factual situation presented through legal categories, based on Gerald Rosenberg's theses on social changes through law. The study concludes that the granted interim orders are not effective, because the powers presented answers that follow the same nature of the policies traditionally developed in Brazil, and that a social change is unlikely through the declaration of the State of Unconstitutional Affairs.
\end{abstract}




\section{Keywords}

State of Unconstitutional Affairs; Supreme Federal Court; interim order; social change.

\section{INTRODUÇÃO}

Em setembro de 2015, o Supremo Tribunal Federal (STF) reconheceu um Estado de Coisas Inconstitucional (ECI) no sistema carcerário brasileiro, ocasionado por violações generalizadas de direitos fundamentais e reiterada inércia estatal. A decretação de tal estado de coisas implicaria a determinação de medidas estruturais flexíveis ${ }^{1}$ a serem manejadas e monitoradas pela Corte, com o auxílio dos demais poderes, órgãos e pessoas afetadas.

Passados mais de três anos desde sua decretação, pouco ou nada mudou na realidade dos milhares de detentos submetidos, diariamente, a condições desumanas de encarceramento. ${ }^{2}$ Muito embora tenha sido saudada como importação bem-vinda por alguns autores (CAMPOS, 2015; RODRIGUEZ, 2015), outros não pouparam críticas à doutrina ${ }^{3}$ do ECI no

1 No mérito, o autor da Arguição de Descumprimento de Preceito Fundamental (ADPF) requeria, entre outros pedidos: a) que fossem determinados ao Governo Federal a elaboração e o encaminhamento ao Supremo, no prazo de três meses, de um plano nacional visando à superação, dentro de três anos, do quadro dramático do sistema penitenciário brasileiro; b) que o aludido plano contivesse propostas e metas; c) que o plano previsse os recursos necessários à implementação das propostas e o cronograma para a efetivação das medidas; d) que o plano fosse submetido à análise do Conselho Nacional de Justiça (CNJ), da Procuradoria-Geral da República (PGR), da Defensoria-Geral da União, do Conselho Federal da Ordem dos Advogados do Brasil (CFOAB), do Conselho Nacional do Ministério Público (CNMP) e de outros órgãos e instituições que desejassem se manifestar e da sociedade civil; e) que o Tribunal deliberasse sobre o plano, para homologá-lo ou impor providências alternativas ou complementares; f) uma vez homologado o plano, fosse determinado aos governos dos estados e do Distrito Federal que formulassem e apresentassem ao Supremo, em três meses, planos próprios em harmonia com o nacional, contendo metas e propostas específicas para a superação do ECI; g) que o Tribunal deliberasse sobre cada plano estadual e distrital, para homologá-los ou impor providências alternativas ou complementares; e h) que o Supremo monitorasse a implementação dos planos nacional, estaduais e distrital, com o auxílio do Departamento de Monitoramento e Fiscalização do Sistema Carcerário (DMF) e do Sistema de Execução de Medidas Socioeducativas do CNJ, em processo público e transparente, aberto à participação colaborativa da sociedade civil.

2 Trata-se de um segundo artigo de estudo dividido em duas partes sobre o ECI. Em outro artigo, expusemos os problemas teóricos e dogmáticos presentes nas hipóteses de cabimento do ECI.

3 Uma doutrina pode ser uma moldura de julgamento, um conjunto de regras, etapas procedimentais a serem seguidas pela Corte ou testes a serem empregados para revisar uma lei ou política pública, muitas vezes 
Direito brasileiro (STRECK, 2015; GLEZER e MACHADO, 2015; DE GIORGI, FARIA e CAMPILONGO, 2015).

Entre os autores de direito constitucional, o ECI parece não ter suscitado tantas controvérsias sobre a sua incorporação, com trabalhos que se limitaram em reproduzir o conteúdo daquilo decidido pelo STF (SANTOS et al., 2015; CALDAS e LASCANE NETO, 2016; ANDRADE e TEIXEIRA, 2016; PEREIRA, 2017); sugerindo sua inserção temática na discussão sobre ativismo judicial (BERNARDI e MEDA, 2016; PENNA, 2017); propondo sua extensão para outros direitos ${ }^{4}$ ou apenas reforçando sua importância em nosso atual cenário social (DANTAS, 2016; CARVALHO, OLIVEIRA e SANTOS, 2017; DUARTE e DUARTE NETO, 2016). O traço comum a todos esses trabalhos é a não problematização quanto às consequências jurídicas e políticas da decretação judicial desse estado de coisas.

Tomado de empréstimo da Corte Constitucional Colombiana (CCC), o ECI não representou a panaceia para os problemas estruturais daquele país, além de contar com importantes opositores no campo acadêmico e ter falhado na prática, dados os tímidos resultados observados na prática (embora simbolicamente significativos no caso dos deslocados internos). ${ }^{5} \mathrm{Na}$ hipótese da superlotação carcerária, por exemplo, o instrumento não obteve os resultados esperados.

A utilização de uma doutrina ${ }^{6}$ que pretende inserir medidas estruturais para alterar um estado fático criado por uma complexa mistura de fatores suscita válidas objeções no campo da separação de poderes, no sentido da possível intromissão do Judiciário em assuntos do Executivo. Contudo, não pretendemos nos voltar a esse ponto, mas, sim, objetivamos questionar a possibilidade de aquela doutrina cumprir suas promessas, levando em consideração o padrão de litígio empregado pelos autores da Arguição de Descumprimento de Preceito Fundamental (ADPF), a trajetória das decisões tomadas pelos três poderes da República posteriormente à declaração do ECI e as discussões sociológicas sobre mudanças sociais por meio do Direito.

Dessa maneira, este artigo pretende realizar a análise de um precedente da Corte Suprema (ADPF 347), partindo do estudo da eficácia das medidas cautelares e da resposta dos três

estabelecida por meio de um precedente. Uma doutrina surge quando uma Corte estrutura uma moldura decisória e a aplica em casos semelhantes (TILLER e CROSS, 2006, p. 518). A nota explicativa se justifica para nos distanciar do conceito corrente no Direito brasileiro de "doutrina".

4 Meda e Bernardi (2016) - direito à moradia - e Oliveira (2016) - direito à liberdade nas comunicações.

5 O ECI declarado na sentença da CCC T - 025/04 não foi suficiente para dar cabo do grave problema dos deslocados internos por conta de conflitos internos armados, muito embora tenha servido para que as autoridades públicas dessem mais atenção à grave situação. Por essa razão, adjetivamos sua existência como simbolicamente significativa, mas de pouca consequência prática (RODRÍGUEZ-GARAVITO, 2009).

6 Ver nota 5. 
poderes, a fim de verificar os impactos da decisão do STF no sentido de reverter o ECI por ele identificado. Estabeleceremos comparações entre o decidido pelo STF e a resposta dos poderes, ou seja, o impacto será avaliado a partir da capacidade de as respostas políticas alterarem a situação apresentada pelo ECI. Para tanto, coletaremos os dados referentes às manifestações do STF, do Executivo Federal e do Legislativo Federal no sentido de responder às determinações exigidas pelo ECI. A pesquisa ocorreu, primordialmente, a partir de buscas nos sítios oficiais dos três poderes, por meio da inserção de palavras-chave nos principais mecanismos de pesquisa, ${ }^{7}$ logo após a decisão do STF.

Tal forma de análise é importante para aferir, a partir dos fatores que circundam o processo de tomada de decisão, o conhecimento de suas regras formais, informações sobre formas de melhorar a política e, ao fim, vias para a oferta de alterações que poderão melhorar seu desempenho (CASHMORE et al., 2010, p. 373-374). Como os métodos dependem das especificidades daquilo que se pretende avaliar (CHANCHITPRICHA e BOND, 2013, p. 65), mapearemos as respostas institucionais formais desses poderes no cumprimento das determinações do STF no âmbito da ADPF 347, quais sejam a articulação conjunta dos três poderes no cumprimento das medidas cautelares no sentido de sanar o ECI e como a própria Corte encara seu papel no sentido de dar cabo a esse estado de coisas.

Por fim, após a análise das respostas dos poderes e seu impacto na solução do ECI, o artigo desenvolverá um ensaio sociológico, a fim de questionar a tentativa judicial de promover mudanças sociais na via top-down, por meio de ação do controle abstrato de constitucionalidade e negligenciando a linguagem política. Tal análise partirá dos marcos teóricos da sociologia das mudanças sociais por meio do Poder Judiciário, especialmente aquelas ligadas à perspectiva do litígio de interesse público e das teses de Gerald Rosenberg (1991), as quais sugerem, em síntese, que Cortes são produtoras de reformas sociais quando já há um apoio geral político e popular para que a mudança ocorra ou quando o processo de mudança já está em curso.

Para fins de registro, críticas a essa doutrina não significam que ignoramos a caótica e calamitosa situação de nossa população carcerária ou que o STF deva cruzar os braços para graves violações de direitos fundamentais. Entretanto, não podemos nos furtar a descrever,

7 No âmbito do STF, a pesquisa foi feita no sítio http://portal.stf.jus.br/, mais especificamente na aba "jurisprudência”, a partir da qual foram utilizadas as seguintes palavras-chave: "Estado de Coisas Inconstitucional”, “ADPF 347”, “Corte Constitucional Colombiana”, "Sistema Carcerário”, etc. Foram coletadas todas as decisões do STF que trataram, diretamente, sobre o tema decididas entre outubro de 2015 e julho de 2018. No caso do Poder Legislativo, foram consultados os sítios da Câmara dos Deputados (http:/ /www2.camara.leg.br/) e do Senado (https://www12.senado.leg.br/hpsenado). No sítio da Câmara, acessamos a aba "Atividade Legislativa" e, em seguida, a aba "Projetos de Lei e Outras Proposições". Foram selecionadas todas as instâncias de proposições legislativas (ex.: PL, PEC, etc.) e inserimos as seguintes palavras-chave: "Estado de Coisas Inconstitucional”, “ADPF 347”, "Corte Constitucional Colombiana”, "Sistema Carcerário”. O mesmo e exato procedimento foi replicado no sítio do Senado. 
explicar e expor os problemas de empréstimos no campo teórico, inclusive para evitar que a situação se agrave, agora que todos os poderes públicos estão na berlinda ${ }^{8}$ para encontrar uma solução rápida e eficaz ao problema, sob pena de a eventual falha do ECI macular a legitimidade do STF e expor os riscos de experimentos decisórios com direitos fundamentais e com as relações institucionais entre os poderes.

\section{O JUlgamento dA MC NA ADPF 347: EXPOSiÇÃO DESCRITIVA dOS VOTOS}

O Partido Socialismo e Liberdade (PSOL) buscou, por meio de ADPF protocolada no dia 27/05/2015, o reconhecimento da figura do ECI relativamente ao sistema penitenciário brasileiro e a adoção de providências estruturais em face de lesões a preceitos fundamentais dos atualmente encarcerados, que o partido alega decorrerem de ações e omissões dos poderes públicos da União, dos estados e do Distrito Federal. A relatoria do caso coube ao Ministro Marco Aurélio, que entendeu cabível a ADPF e o reconhecimento de uma nova modalidade de inconstitucionalidade no Direito brasileiro, o ECI.

Após descrever a deplorável situação da população carcerária no Brasil, o relator confirmou que dela decorrem inúmeras violações de direitos fundamentais e humanos, ${ }^{9}$ bem como de preceitos básicos presentes na Lei de Execução Penal (LEP - Lei n. 7.210/1984). Tais violações, de acordo com o Ministro, não impactariam, tão somente, situações subjetivas individuais, mas afetariam toda a sociedade. Portanto, conclui que, no Brasil, cárceres não servem à ressocialização.

A responsabilidade por essa situação recai sobre os três poderes, em todos os níveis federais, muito embora o problema do ECI não seja de formulação e implementação de políticas públicas, ou de interpretação e aplicação da lei penal, mas da falta de coordenação institucional para sua concretização. Trata-se de uma situação de inércia ou omissão que ocasiona problemas estruturais na concretização normativa da Constituição e da legislação correlata, e nada é feito para melhorar a situação. A ausência de medidas legislativas, administrativas e orçamentárias eficazes representa falha estrutural a gerar tanto a violação sistemática dos direitos quanto a perpetuação e o agravamento da situação.

8 Porquanto, como requisito para declarar um ECI, o STF teve de atestar a ineficiência e/ou inércia conjunta de todos os poderes da República.

9 O princípio da dignidade da pessoa humana (art. $1^{\circ}$, inciso III); a proibição de tortura e tratamento desumano ou degradante de seres humanos (art. $5^{\circ}$, inciso III); a vedação da aplicação de penas cruéis ( $\operatorname{art.~} 5^{\circ}$, inciso XLVII, alínea "e"); o dever estatal de viabilizar o cumprimento da pena em estabelecimentos distintos, de acordo com a natureza do delito, a idade e o sexo do apenado (art. $5^{\circ}$, inciso XLVIII); a segurança dos presos às integridades física e moral (art. $5^{\circ}$, inciso XLIX); e os direitos à saúde, à educação, à alimentação, ao trabalho, à previdência e à assistência social (art. $6^{\circ}$ ) e à assistência judiciária. 
Em face desses entraves, o STF deve desempenhar um papel importante, e uma das formas de atuação seria dar vazão ao litígio estrutural por meio do ECI, cuja utilização dependerá da demonstração de três pressupostos: 1) situação de violação generalizada de direitos fundamentais; 2) inércia ou incapacidade reiterada e persistente das autoridades públicas em modificar a situação identificada; e 3) superação das transgressões, de modo que exija a atuação de todas as autoridades políticas.

Nesse momento do voto, Marco Aurélio sustenta que é impossível indicar, com segurança, os problemas brasileiros que se encaixariam nesse conceito e, em seguida, cita nominalmente os exemplos do saneamento básico, da saúde pública e da violência urbana. Porém, confirma que o caso do sistema carcerário seria uma hipótese de certeza positiva. Dessa maneira, caberia ao STF, excepcionalmente, atuar de forma mais assertiva, por ser o órgão capaz de superar bloqueios políticos e institucionais que vêm impedindo o avanço de soluções ação de retirar os demais poderes da inércia, catalisar debates e novas políticas públicas, coordenar ações e monitorar os resultados.

No caso da população carcerária, seriam dois os bloqueios institucionais presentes: sub-representação parlamentar (presos não podem votar ou receber votos) e impopularidade dos indivíduos (não há prioridade política dos gastos públicos com essas pessoas, ou seja, constituem uma minoria socialmente desprezada). Tendo em vista que a opinião pública está no coração da estrutura democrático-parlamentar, argumenta o relator, ignorá-la poderia significar não só o fracasso das políticas defendidas pelos parlamentares, mas também das tentativas de reeleição a cargos no Legislativo e no Executivo. Nesse sentido, diferentemente do que ocorre com a saúde pública, nas palavras do Ministro (ADPF 347, 2015, DJe 09/09/2015, p. 33):

Comparem com a saúde pública: há defeitos estruturais sérios nesse campo, mas tem-se vontade política em resolvê-los. Não existe um candidato que não paute a campanha eleitoral, entre outros temas, na melhoria do sistema. Todos querem ser autores de propostas que elevem a qualidade dos serviços. Deputados lutam pela liberação de recursos financeiros em favor da população das respectivas bases e territórios eleitorais. A saúde pública sofre com déficits de eficiência, impugnados judicialmente por meio de um sem-número de ações individuais, mas não corre o risco de piora significativa em razão da ignorância política ou do desprezo social. O tema possui apelo democrático, ao contrário do sistema prisional.

Nesse cenário, de acordo com Marco Aurélio, de bloqueios políticos insuperáveis, fracasso de representação, pontos cegos legislativos e temores de custos políticos, a intervenção do Supremo, na medida correta e suficiente, não poderia sofrer qualquer objeção de natureza democrática. Não é autorização de substituição de tarefas próprias dos demais Poderes, pois o STF deve superar bloqueios políticos e institucionais sem afastar esses Poderes dos processos de formulação e implementação das soluções necessárias. Deverá agir, porém, em diálogo com os outros 
Poderes e com a sociedade. Caberia ao Supremo catalisar ações e políticas públicas, coordenar a atuação dos órgãos do Estado na adoção dessas medidas e monitorar a eficiência das soluções.

Cumpriria ao STF formular ordens flexíveis, com margem de criação legislativa e de execução a serem esquematizadas e concretizadas pelos demais Poderes, cabendo-lhe reter jurisdição para monitorar a observância da decisão e o sucesso dos meios escolhidos. O tribunal funcionaria como um coordenador institucional que produz um efeito desbloqueador, e não como um elaborador de políticas públicas.

Fachin, Barroso, Zavascki, Weber, Fux, Cármen Lúcia, Celso de Mello e Lewandowski repetiram, com pouca variação, os argumentos defendidos por Marco Aurélio, o que nos isenta de reproduzi-los no momento.

2. O ReSCALDO dA ADPF 347: A RESPOSTA dOS PODERES DA REPÚBLICA E O IMPACTO DA MEDIDA CAUTELAR NO ECI

\section{2. i. Poder Judiciário: Supremo Tribunal Federal}

2. I. I. A EFICÁcia das MEdidas CAUTElares DEFERIDAs

Embora tendo declarado o ECI, o STF não julgou o mérito da ação e apenas deferiu uma pequena porção das medidas cautelares requeridas pelo autor, conforme Quadro 1, a seguir:

QUAdro 1 - MEDIDAS CAUTELARES REQUERIDAS E MEDIDAS CAUTELARES DEFERIDAS

MEDIDAS CAUTELARES REQUERIDAS

A) AOS JUÍZES E TRIBUNAIS - MOTIVAÇÃO EXPRESSA

PELA NÃO APLICAÇÃO DE MEDIDAS CAUTELARES

ALTERNATIVAS À PRIVAÇÃO DE LIBERDADE.

B) QUE REALIZEM, EM ATÉ 90 DIAS, AUDIÊNCIAS DE CUSTÓDIA.

C) QUE CONSIDEREM O QUADRO DRAMÁTICO DO SISTEMA PENITENCIÁRIO NO MOMENTO DE MEDIDAS CAUTELARES PENAIS, NA APLICAÇÃO DA PENA E DURANTE A EXECUÇÃO PENAL.

\section{MEDIDAS CAUTELARES DEFERIDAS}

B) AOS JUÍZES E TRIBUNAIS - QUE REALIZEM, EM ATÉ 90 DIAS, AUDIÊNCIAS DE CUSTÓDIA.

H) $\dot{A}$ UNIÃO - QUE LIBERE AS VERBAS DO FUNDO PENITENCIÁRIO NACIONAL. 
D) QUE ESTABELEÇAM, QUANDO POSSÍVEL, PENAS

ALTERNATIVAS À PRISÃO.

E) QUE ABRANDEM OS REQUISITOS TEMPORAIS

PARA A FRUIÇÃO DE BENEFÍCIOS DOS PRESOS,

QUANDO AS CONDIÇÕES DE CUMPRIMENTO DA

PENA FOREM SEVERAS.

F) AO JUIZ DA EXECUÇÃO PENAL - QUE ABATA, DA

PENA, O TEMPO DE PRISÃO, SE AS CONDIÇÕES DE

CUMPRIMENTO FOREM MAIS SEVERAS DAQUELAS

INICIALMENTE FIXADAS.

G) AO CNJ - QUE COORDENE MUTIRÃO CARCERÁRIO.

H) $\dot{A}$ UNIÃO - QUE LIBERE AS VERBAS DO FUNDO

PENITENCIÁRIO NACIONAL.

A quase totalidade das medidas cautelares requeridas pelo autor da ação foram dirigidas ao Poder Judiciário e a seus órgãos, muito embora o tribunal tenha rejeitado grande parte delas por temer intervir em assuntos do Poder Legislativo (e) ou pela redundância do requerido ${ }^{10}$ (g), especialmente daqueles pedidos que já exigiam de juízes e tribunais decisões com motivações expressas $(a, c$ e $f$ ).

O deferimento da medida cautelar que obrigava a realização de audiências de custódia representa um importante avanço na proteção dos direitos daqueles detidos em flagrante, contudo a medida cautelar na ADPF 347 (09/09/2015) não foi a primeira manifestação do tribunal sobre o tema, o qual já havia decidido por sua constitucionalidade e obrigatoriedade na Ação Direta de Inconstitucionalidade (ADI) 5.240 (20/08/2015), indicando a necessidade de adoção da audiência de apresentação por todos os tribunais do país. Portanto, essa medida cautelar não inovou o ordenamento jurídico brasileiro.

A única medida cautelar dirigida ao Executivo importava no descontingenciamento dos recursos do Fundo Penitenciário Nacional (Funpen), para que fossem alocados às finalidades que justificaram sua criação. Contudo, no curso do julgado, o então advogado-geral da

O CNJ, desde 2010, realizava mutirões carcerários. 
União, Luís Inácio Lucena Adams, informou aos ministros que tais recursos não estavam mais contingenciados. Por essa razão, o Ministro Zavascki reconheceu que o problema não seria, tanto, a falta de recursos, mas a inexistência de um plano de ação para alocá-los. O Ministro Barroso, a seu turno, questionou a utilidade da medida cautelar em face da notícia do advogado-geral da União, o que o levou a estabelecer um prazo de 60 dias para a demonstração das informações trazidas.

Por fim, a última medida cautelar, deferida de ofício, não é capaz de afetar a situação do ECI, porquanto apenas requer da União e dos Estados a apresentação de diagnóstico completo acerca da situação do sistema carcerário no âmbito de suas respectivas atuações, informações essas, que, segundo Barroso, não constavam nos autos. A última medida cautelar é interessante, pois demonstra que o STF não tinha tanta segurança quanto à caracterização do ECI, por ter de demandar aos entes federados informações desconhecidas pelos ministros. ${ }^{11} \mathrm{Se}$ a decretação do ECI depende da demonstração de violação generalizada e falência na atuação dos poderes políticos, em todos os níveis da federação, como podemos ter certeza de sua caracterização no Brasil se o STF precisa de mais informações?

2. I.2. DeCisÕes MONOCRÁticAs E PLENÁRIAS POSTERIORES A MEDIDA CAUTELAR NA ADPF 347 Até a data da redação do presente artigo (07/2018), quase três anos depois da paradigmática decisão, a União não cumpriu a medida cautelar (MC) ex officio de apresentar informações detalhadas sobre o sistema carcerário brasileiro. Não há notícias, igualmente, acerca da apresentação das informações dirigidas aos estados, tendo o estado de Goiás requerido, no que foi deferida, dilação de prazo para a juntada de seus dados. ${ }^{12}$

Os estados de Mato Grosso do Sul, Piauí, Alagoas, Goiás, Rio Grande do Sul, São Paulo, Sergipe e Ceará apresentaram petição afirmando não terem notícia da liberação de recursos do Funpen, arguindo o descumprimento da medida acauteladora de descontingenciamento. $\mathrm{O}$ Ministro Marco Aurélio intimou a União para que informasse as razões do não cumprimento. ${ }^{13}$

O Executivo respondeu à determinação judicial com atraso, editando, em 19/12/2016, a Medida Provisória (MP) n. 755/2016, que dispunha sobre a desburocratização do repasse dos recursos do Funpen aos estados. Na exposição de motivos da MP, o Ministro da Justiça citou a ADPF 347 como uma das razões para a medida normativa. Após a perda de eficácia daquela MP, o Executivo editou outra (n. 781/2017), reprisando o conteúdo da anterior quase literalmente, que depois foi convertida na Lei n. 13.500/2017.

11 Para mais informações sobre os problemas do cabimento do ECI, conferir "A incrível doutrina de um caso só: análise do Estado de Coisas Inconstitucional na ADPF 347” (no prelo), de nossa autoria.

12 Decisão Monocrática na ADPF 347, DJe 25/11/2015, Relator Marco Aurélio.

13 Decisão Monocrática na ADPF 347, DJe 30/06/2016, Relator Marco Aurélio. 
Em função da resposta normativa do Executivo (edição das MPs), o autor da ação requereu, sendo deferida ${ }^{14}$ emenda à inicial da ADPF (ou recebimento como ADI), no sentido de incluir artigos das medidas provisórias, os quais estabeleceriam, supostamente, novas finalidades ao Funpen, alheias à função de incremento do sistema carcerário.

Fora dos autos da ADPF 347, a Suprema Corte tem recebido uma enorme quantidade de reclamações constitucionais propostas (e deferidas) em função do descumprimento da realização de audiências de custódia por parte de varas criminais dos mais diversos locais do país. Em termos estratégicos, aparentemente, os réus preferem acessar o STF a impetrar habeas corpus ao Tribunal de Justiça correspondente, para que lhes seja garantido aquele direito fundamental. ${ }^{15}$

O Ministro Marco Aurélio indeferiu a ADPF 404/DF, ${ }^{16}$ proposta pela Confederação dos Servidores Públicos do Brasil (CSPB), para que fosse reconhecido o ECI no sistema carcerário da Bahia. De acordo com a inicial, no ano de 2014 foi publicado edital de abertura de concurso público naquele estado para o provimento de 490 cargos na administração penitenciária. Porém, mesmo após o edital, o estado ainda contratava pessoas para ocupar esse cargo de forma provisória. Ao permitir a contratação temporária, o estado estaria perpetuando a precariedade do sistema carcerário baiano, argumentavam os autores.

Para o Ministro, não seria possível alegar o ECI no caso (ADPF 404), mecanismo excepcional de atuação jurisdicional, ante a paralisia institucional extraordinária, no sistema prisional por meio da ilegalidade na contratação de agentes penitenciários, mesmo porque tal instituto não serviria para impugnar atos administrativos tidos como ilegais ou abusivos, ainda que reiterados, no âmbito de ente federado.

14 Decisões Monocráticas na ADPF 347, DJe 09/02/2017 e DJe 03/10/2017, Relator Marco Aurélio.

15 Cf., exemplificativamente, as seguintes decisões monocráticas: Rcl 30.962/RN, DJe 28/06/2018, Relator Edson Fachin; Rcl 28.808/RS, DJe 18/06/2018, Relator Alexandre de Moraes; Rcl 29.175 MC/SC, DJe 01/02/2018, Relator Roberto Barroso; Rcl 28.173/RJ, DJe 01/02/2018, Relator Edson Fachin; Rcl 28.977 MC/RS, DJe 17/11/2017, Relator Celso de Mello; Rcl 28.871 MC/RS, DJe 06/11/2017, Relator Celso de Mello; Rcl 27.207/RS, DJe 31/10/2017, Relator Ricardo Lewandowski; Rcl 28.079 MC/MT, DJe 01/09/2017, Relator Roberto Barroso; Rcl 27.730/RJ, DJe 25/08/2017, Relator Gilmar Mendes; Rcl 27.748/SC, DJe 17/08/2017, Relator Alexandre de Moraes; Rcl 26.604 MC/GO, DJe 17/08/2017, Relator Roberto Barroso; Rcl 27.074/RJ, DJe 18/08/2017, Relator Gilmar Mendes; Rcl 27.393/SC, DJe 19/06/2017, Relator Gilmar Mendes; Rcl 26.645/RJ, DJe 12/05/2017, Relator Gilmar Mendes; Rcl 26.221/RJ, DJe 11/05/2017, Relator Gilmar Mendes; Rcl 26.729/SE, DJe 11/05/2017, Relator Gilmar Mendes; Rcl 26.055/GO, DJe 14/02/2017, Relator Edson Fachin; Rcl 25.560 MC/PA, DJe, 01/02/2017, Relator Roberto Barroso; Rcl 25.518 MC/PA, DJe, 01/02/2017, Relator Roberto Barroso; Rcl 24.752 MC/DF, DJe 14/10/2016, Relator Ricardo Lewandowski; Rcl 24.536/DF, DJe $01 / 08 / 2016$, Relator Edson Fachin. 
A Associação Nacional das Defensoras e Defensores Públicos (Anadep) propôs reclamação constitucional em face do Poder Executivo Federal e dos Estados, Tribunais de Justiça, Tribunais Regionais Federais (TRF), Ministério Público Federal (MPF) e Ministérios Públicos Estaduais (MPE), todas autoridades, supostamente, omissas na adoção de medidas voltadas à implementação da audiência de custódia, em especial por não terem respeitado o prazo de 90 dias estipulado pelo STF na medida cautelar $b$ da ADPF. A associação requereu, ainda, que o STF estipulasse, com maior grau de detalhamento, as medidas a serem tomadas para que as audiências fossem efetivadas de maneira expedita.

O relator do caso, o Ministro Dias Toffoli, ${ }^{17}$ considerou que, para ser parte na Rcl, seria necessária a demonstração de um efetivo prejuízo advindo da não observância dos julgamentos do STF, o que não seria constatado na hipótese, tendo em vista que a reclamante fora criada para defender os interesses de seus membros (direitos, prerrogativas, etc.), e os atos impugnados não teriam desrespeitado as prerrogativas, os direitos ou os interesses da classe representada pela Anadep, de modo a legitimar sua atuação em sede de reclamação.

Por fim, o Ministro Dias Toffoli negou seguimento à Rcl 26.111/DF, ${ }^{18}$ proposta pela Defensoria Pública da União (DPU) em face do presidente do Tribunal de Justiça do Estado do Amazonas (TJAM) e da Justiça de Primeiro Grau do Amazonas, com vistas a remediar as consequências decorrentes das rebeliões nos presídios que ocorreram nesse estado, reestabelecendo a autoridade da decisão do STF na ADPF 347, quanto ao ECI. A DPU requeria aos juízes da execução penal da comarca de Manaus a imediata progressão de regime e o cumprimento da Súmula Vinculante 56; em relação aos presos provisórios, que também fossem mantidos encarcerados apenas até o limite da capacidade de cada presídio; o desativamento do presídio Vidal Pessoa, em razão de sua incapacidade estrutural; a suspensão da remessa de presos para presídios da capital oriundos de comarcas dos interiores; e inspeção dos locais de encarceramento no interior do estado.

O relator considerou que a reclamante não conseguiu comprovar nos autos o efetivo descumprimento da decisão da Corte por parte das autoridades reclamadas, uma vez que alegou abstratamente a falta de cumprimento das medidas necessárias à implementação do quanto reconhecido pelo Plenário ao apreciar a MC na ADPF 347, o mesmo valeria para a Súmula Vinculante 56, ou seja, a ausência de indicação de qualquer ato concreto passível de controle em contraste com a decisão paradigma inviabilizaria a reclamação.

O Recurso Extraordinário (RE) 641.320/RS ${ }^{19}$ talvez seja a mais notória manifestação do STF pós-ADPF 347 sobre os problemas estruturais da sociedade brasileira que acarretam

Rcl 23.872/DF, DJe 27/05/2016.

18

DJe 25/04/2017.

19

DJe $01 / 08 / 2016$. 
violações generalizadas de direitos fundamentais e que, supostamente, dependem do Judiciário para serem solucionadas.

O RE, julgado sob o regime da repercussão geral (Tema 423), pretendia analisar a viabilidade de alteração do regime de cumprimento da pena enquanto não existisse estabelecimento adequado, de acordo com a LEP, compatível com o regime inicialmente fixado. No caso de origem, o MP do Rio Grande do Sul pretendia que fosse alterada decisão que fixou prisão domiciliar, em razão da inexistência de estabelecimento estatal que cumprisse os requisitos do regime semiaberto.

O relator, Gilmar Mendes, identificou o problema no sistema de progressão de regime no Estado brasileiro, pois as vagas nos sistemas aberto e semiaberto estariam aquém do demandado, além de não serem distribuídas uniformemente no território nacional. Ademais, seria possível constatar um contingente, de acordo com dados de 2014, de mais de 30 mil pessoas no regime fechado aguardando abertura de vagas no semiaberto. Alguns estados, inclusive, simplesmente não adotavam o regime aberto, o que fazia que a maioria dos apenados estivesse em regime diverso daquele estipulado na lei.

De acordo com o relator, a manutenção do condenado em regime mais gravoso daquele fixado na pena e na lei violaria o direito à individualização da pena, portanto, haveria um direito a ser inserido em um regime inicial compatível com o título condenatório e à progressão de regime de acordo com o mérito. Com efeito, não seria possível justificar a manutenção em regime mais gravoso com base na ponderação dos direitos dos condenados em face dos interesses de segurança pública da sociedade. Não obstante tais conclusões, tampouco considerou o Ministro ser possível determinar prisão domiciliar no caso de falta de vagas nos regimes aberto ou semiaberto, apesar de não as descartar, enquanto as propostas alternativas não fossem estruturadas. ${ }^{20}$

Como forma de solucionar o impasse, o Ministro sugeriu alternativas que não estavam presentes na legislação pertinente, mas concluiu que suas medidas não violavam o princípio da legalidade, muito embora não tenha indicado ou justificado o porquê. ${ }^{21}$ A seguir, elencamos as alternativas criadas pelo Ministro.

20 Além de considerá-las de difícil fiscalização, o relator ressaltou que a prisão domiciliar poderá ser problemática quando o crime tiver sido cometido, por exemplo, contra membros da família, quando o apenado ainda mantiver íntima relação com outros criminosos residentes em seus arredores, além de criar um ônus às famílias (alimentação, saúde, etc.).

21 Segue trecho do voto: "Com isso, ainda que falte previsão expressa na lei para adoção dessas medidas em execução penal, tenho que não haverá violação ao princípio da legalidade - art. $5^{\circ}$, XXXIX”. O argumento da legalidade foi utilizado para indeferir significativa quantidade das medidas cautelares requeridas na ADPF 347, mas nem sequer foi problematizado como óbice no presente RE, que estipulava medidas muito semelhantes. 
A saída antecipada de sentenciado no regime com falta de vagas: o sentenciado em regime semiaberto pode ter saída antecipada para ser colocado em liberdade eletronicamente monitorada; ao apenado no regime aberto, poderá ser proposta a substituição por penas alternativas ou estudo, desde que cumpridos os requisitos objetivos e subjetivos da progressão.

A liberdade eletronicamente monitorada ao sentenciado que sai com antecipação ou é posto em prisão domiciliar por falta de vagas: nessas ocasiões, reservadas àqueles que estiverem cumprindo penas nos regimes semiaberto ou aberto, será possível e desejado que o apenado trabalhe ou estude, para evitar o ócio e a criação de ônus econômico para sua família.

O cumprimento de penas restritivas de direito elou estudo ao sentenciado que progride ao regime aberto: para Gilmar Mendes, a melhor saída para o condenado ao regime aberto não é a prisão domiciliar, mas a substituição da pena privativa de liberdade por restritivas de direitos.

Nessa altura de seu voto, o Ministro considera ter encerrado a discussão jurídica posta em análise pelo tribunal, mas pondera ser imperioso discutir sobre a possibilidade de instituir uma decisão de natureza manipulativa.

O relator considera a LEP satisfatória, mas credita o colapso do sistema carcerário à parte administrativa. Sem mencionar ou problematizar o ECI, Mendes cita a ADPF 347 apenas como uma demonstração, entre outras causas julgadas ou pendentes de julgamento no tribunal (outras foram os RE 580.252, ADI 5.170 e RE 592.581), dos problemas enfrentados pelo sistema carcerário brasileiro. Tendo em vista a complexidade do problema, sugere a necessidade de tomar decisões de caráter plástico, que sirvam de plataforma para a adequação da realidade aos direitos afirmados pela Constituição e pelas leis do país, ou seja, uma decisão a ser manejada que modifica o conteúdo do ordenamento jurídico.

O Ministro fez um apanhado jurisprudencial sobre as vezes nas quais o STF, a pretexto de realizar interpretação conforme, em verdade, alterou ou acresceu sentido à lei (ADI 1.105, ADPF 54, ADI 4.357, Petição (PET) 3.388 e ADPF 347), como forma de justificar a recepção, entre nós, das sentenças manipulativas de efeitos aditivos.

Muito embora reconhecendo os limites dos REs, o relator aponta que (RE 641.320/RS, DJe 11/05/2016, p. 40):

podemos fazer um esforço para resolver a questão de forma estruturante, além do simples estabelecimento de teses jurídicas. Podemos avançar, determinando a observação de ferramentas que serão essenciais na implementação dos direitos dos sentenciados e no atendimento ao programa legal quanto à execução penal.

Em conclusão de sua argumentação, sugere que os órgãos do Poder Judiciário e do MP devem desenvolver e fiscalizar as propostas debatidas no caso, especialmente o CNJ e o CNMP. Com o apoio dos conselhos, considera o Ministro, o tribunal poderá adotar medidas concretas de ordem administrativa e de política judiciária a serem fiscalizadas pelo STF, sem a necessidade de reformas administrativas. 
Como precedente dessa forma de medidas concretas e estruturais, o Ministro relembra a ADPF 347, mas a elas atribui outra nomenclatura: a técnica do complex enforcement. Gilmar Mendes conceitua complex enforcement, sem que tenha apresentado uma tradução livre ou oficial, como "um tipo de litígio no qual um segmento grande da realidade social é denunciado com ofensivo ao direito e transformado por ordens judiciais de fazer ou não fazer".

Em síntese, o Ministro recomendou o seguinte: 1) o CNJ deverá apresentar, em até 180 dias, projeto de estruturação do Cadastro Nacional de Presos; 2) o CNJ deverá apresentar relatório sobre a implantação das centrais de monitoração e penas alternativas; 3) o CNJ, deverá elaborar relatório para expansão do Programa Começar de Novo e adoção de outras medidas buscando o incremento da oferta de estudo e de trabalho aos condenados; e 4) o CNJ deverá, em 1 ano, apresentar relatório com projetos para o aumento do número de vagas nos regimes semiaberto e aberto.

O então presidente do STF e do CNJ, o Ministro Ricardo Lewandowski, salientou problemas no voto do relator, especialmente quanto às pautas a serem impostas ao CNJ, por conta da capacidade de o STF fixar as atribuições daquele órgão e sua agenda, as quais são definidas pelos conselheiros e congressos nacionais de magistratura. Argumentou, ademais, que o CNJ já possui programas que analisam a unificação da execução penal de forma eletrônica, a existência de programas mais importantes ou mais bem estruturados do que o Começar de Novo e que a criação de vagas seria uma medida a afetar o Executivo. Entretanto, confirma estar de acordo com as conclusões jurídicas do Ministro, mas não explicitando onde, como e em que extensão convergiam com o voto do relator.

Contemporizando as divergências, Fachin, o seguinte a votar, comenta que o relator fez apenas sugestões ao CNJ, cabendo a este a liberdade para avaliar e desenvolver as propostas, muitas delas, inclusive, convergentes com projetos em andamento no Conselho. Em debates, Lewandowski pontua que, caso fossem meras sugestões, estaria de acordo, mas as determinações do relator estariam de encontro às políticas em curso ou a serem implantadas no CNJ. Em resposta, o relator insiste não serem recomendações, mas determinações judiciais obrigatórias.

Teori Zavascki, que votou após pedido de vistas, considerou que o ponto sobre as determinações feitas ao CNJ restou prejudicado em razão das informações apresentadas pelo presidente do CNJ acerca das políticas lá desenvolvidas, mas não se aprofunda na natureza daquelas determinações do relator e acaba afirmando que segue o voto do relator. Marco Aurélio, por sua vez, não discute o tema de forma mais ampla, restringindo-se a decidir o caso concreto. Celso de Mello reconhece o ECI no caso, porém trata o tema de forma genérica e abstrata, reutilizando o conteúdo de votos anteriores. Por fim, vota com o relator, embora não mencione nada sobre as sugestões do relator feitas ao CNJ.

Portanto, conforme o demonstrado nos debates do acórdão, o tribunal concordou com a tese fixada pelo relator acerca da progressão de regime na ausência de estabelecimentos adequados, contudo, rechaçou suas sugestões aditivas. A ementa do acórdão, por sua vez, redigida 
exclusivamente pelo relator do caso, ${ }^{22}$ contrariando as expectativas do decidido coletivamente e descrito nesta seção, contém um tópico específico que trata do caráter aditivo da decisão e detalha as determinações impostas ao CNJ.

\subsection{Poder Legislativo: O PL N. $736 / 2015$}

Ainda que tomemos com ressalvas a tese defendida por Thamy Pogrebinschi (2011), o legislador brasileiro não permanece totalmente inerte diante de decisões do STF no controle concentrado de constitucionalidade, contrariando prognósticos dos defensores de um ofuscamento do Parlamento pela sombra ativa do Judiciário. Não foi diferente com o ECI.

O Senador Antônio Carlos Valadares (PSB/SE) apresentou projeto de lei (n. 736/2015) para regulamentar o ECI. Em sua justificativa, o Senador caracterizou o ECI como uma criação judicial preocupante, especialmente por conta da usurpação das competências dos demais poderes, Executivo e Legislativo, bem como por representar o ativismo judicial do STF. Portanto, salientou que essa heterodoxa posição do Judiciário em face dos demais poderes precisava de balizas normativas, a fim de harmonizar os princípios da separação de poderes e da reserva do financeiramente possível. A preocupação do Senador, portanto, parece ser com “a consolidação dessa corrente jurisprudencial”, conforme sua própria manifestação na exposição de motivos da lei.

Como forma de criar limites ao poder do STF, o Senador sugere a inserção do Compromisso Significativo, desenvolvido pela Corte Constitucional da África do Sul, conceituado como a ponte para a construção de uma solução pactuada, participativa entre os poderes políticos e os atingidos pela violação de direitos, sob a fiscalização do Judiciário. ${ }^{23} \mathrm{Ou}$ seja, o Senador não nega a existência do ECI, apenas cria balizas com base no que acredita ser a prática da Corte Constitucional da África do Sul.

O PL está há três anos - desde 20/11/2015 para ser mais preciso - aguardando a designação de um relator ou uma relatora na Comissão de Constituição, Justiça e Cidadania (CCJC Secretaria de Apoio à Comissão de Constituição, Justiça e Cidadania).

22 A inserção de informações não discutidas no acórdão, equivocadas ou que expressam apenas a compreensão do voto vencedor, é constante na redação de ementas, infelizmente, tomadas como o resultado exato de uma decisão do STF (MAGALHÃES e SILVA, 2014).

23 Segue artigo do projeto de lei: “Art. $9^{\circ}$-B. Reconhecido o estado de coisas inconstitucional, nos termos do art. $9^{\circ}$-A, o Supremo Tribunal Federal determinará a celebração de compromisso significativo entre o Poder Público e os segmentos populacionais afetados pela ação ou omissão, com o intuito de tornar efetivo o preceito fundamental, ponderados os princípios e normas constitucionais envolvidos. Parágrafo único. O compromisso significativo consiste em constante intercâmbio entre os segmentos populacionais afetados e o Estado, em que as partes tentam celebrar acordo para a formulação e implementação de programas socioeconômicos que visem a afastar a violação ao preceito fundamental detectada”. 


\subsection{Poder Executivo}

Antes de apresentar a manifestação do Executivo, é importante reforçar que nem todas as manifestações convergentes do poder político aos ditames de uma decisão judicial poderão ser a ela creditadas, porquanto o Poder Executivo já estava mobilizado na atenuação do problema carcerário. ${ }^{24}$ Por essa razão, apenas focaremos naquelas medidas decorrentes, expressamente, do ECI.

O Poder Executivo, atendendo aos ditames da medida cautelar do STF, editou MPs (n. 755 e 781) que visavam alterar a lei que criou o Funpen (LC n. 79/94), cuja finalidade é proporcionar recursos e meios para financiar e apoiar as atividades de modernização e aprimoramento do Sistema Penitenciário Brasileiro. ${ }^{25}$ As MPs proporcionaram uma maior desburocratização no repasse dos valores do fundo aos estados e a proibição do contingenciamento, aprimoraram antigas e acrescentaram novas aplicações aos recursos. ${ }^{26}$

O partido político autor da ação requereu a emenda da inicial (ou, alternativamente, o seu recebimento como ADI) para acrescentar as MPs, justificando que teriam acrescido finalidades alheias (políticas de redução da criminalidade e inteligência policial) ao primordial intento do Funpen de aprimorar o sistema penitenciário, reduzido a fonte de custeio do fundo e permitido a transferência de superávit do fundo para outras destinações. No pedido de aditamento, o autor sustentou que a saída para o problema não seria a construção de mais presídios e aventou a necessidade de combate à cultura do encarceramento, porém acrescentou que "gastos elevados terão de ser realizados pelos poderes públicos, visando à criação de novas vagas no sistema prisional”. Ao longo do pedido, o autor da ADPF deixa claro que tal alteração legislativa via MP implicou "mais um episódio de descumprimento da referida decisão do STF". ${ }^{27}$

24 O Executivo não está cego ao problema, vide as ações do Ministério da Saúde (MS, Plano Nacional de Saúde no Sistema Penitenciário - PNSSP -, de 2003, e Política Nacional de Atenção Integral à Saúde das Pessoas Privadas de Liberdade no Sistema Prisional - PNAISP -, de 2014), do Ministério da Educação (MEC), estabelecendo as Diretrizes Nacionais para Educação nas Prisões, e as leis frutos de projetos do Executivo, como o Programa Nacional de Segurança Pública com Cidadania (Pronasci, Lei n. 11.530/2007). O Executivo, ademais, apresentou a MP n. 678/2015 (24/06/2015), posteriormente convertida na Lei n. 13.190/2015, estendendo o Regime Diferenciado de Contratações Públicas (RDC) para as licitações e contratos de construção, ampliação e reforma de estabelecimentos penais e unidades de atendimento socioeducativo e nas ações de segurança pública.

25 Os recursos consignados ao Fundo são aplicados em construção e ampliação de estabelecimentos penais; formação, aperfeiçoamento e especialização do serviço penitenciário; aquisição de material permanente, equipamentos e veículos, entre outros (art. $3^{\circ}$ da LC n. 79/94).

26 Programas de alternativas penais à prisão, políticas de redução da criminalidade e construção, reforma, ampliação e aprimoramento de estabelecimentos penais e de unidades de execução de medidas socioeducativas de inserção em regime de semiliberdade e internação em estabelecimento educacional.

27 Petição de Aditamento à ADPF n. 347, com pedido de concessão de MC apresentado pelo PSOL em 09/01/2017. 
2.4. BALANÇO Do impacto do ECI: RESPOSTA DOS PODERES E CONSEQUÊNCIAS IMPREVISÍVEIS As medidas cautelares deferidas pelo STF surtiram pouco ou nenhum impacto na melhoria do ECI declarado na ADPF 347 por conta das razões apresentadas a seguir.

Tendo em vista que o ECI depende da falha estrutural dos três poderes e de sua consequente ação conjunta para que seja superado, a concentração de medidas cautelares direcionadas ao Judiciário não será suficiente para, de acordo com as próprias premissas do tribunal, atenuar as violações generalizadas de direitos fundamentais. As audiências de custódia, ${ }^{\mathbf{2 8}}$ muito embora essenciais para a garantia de direitos básicos, não atingem a população carcerária que sofreu e sofre as violações generalizadas e amplamente descritas na inicial e nos votos dos ministros. Com efeito, as audiências poderão impedir, provavelmente (o argumento é empírico, não normativo), a entrada de novas vítimas, mas nada poderão fazer pelos já encarcerados.

Os estudos sobre mudança e estabilidade do direito (HATHAWAY, 2001; STONE SWEET, 2002) sugerem que as decisões judiciais estabeleçam linhas argumentativas de efeitos imprevisíveis, ou até indesejados, após sua edição. As decisões judiciais posteriores que orbitam o julgamento da MC na ADPF 347 demonstram que o efeito vinculante está sendo usado para que interessados acessem o STF diretamente a fim de que suas audiências de custódia sejam realizadas, em especial em pequenas comarcas dos interiores dos estados. O tribunal, além das medidas de cumprimento da ação principal que terá de acompanhar de forma constante quando do julgamento do mérito, terá de controlar, individualmente, a regularidade do cumprimento dessa medida cautelar nas inúmeras comarcas de nosso continental país.

$\mathrm{O}$ acesso individual, rápido e fácil à Corte foi um dos requisitos criados pela Corte Colombiana para a criação do ECI, mas omitido pelo STF, que optou por uma tríade de requisitos para justificar a incidência deste. A ação de tutela colombiana pode ser manejada por qualquer pessoa, e violações sistemáticas de direitos fundamentais originadas de uma mesma situação fática acarretariam no abarrotamento da pauta da CCC, ensejando a necessidade de uma decisão única de efeitos gerais por parte dessa Corte. Os autores da ADPF e o próprio STF, provavelmente, omitiram esse requisito no empréstimo da doutrina por conta do acesso restrito à Suprema Corte pela via concentrada, porém o efeito vinculante de uma decisão na ADPF poderá franquear o acesso individual e direto à Corte, por exemplo, de um encarcerado que se sinta prejudicado no cumprimento das medidas cautelares ou daquelas criadas no mérito em fase de monitoramento.

Embora o tribunal tenha almejado construir uma retórica de deferência e cumplicidade em relação aos demais poderes da República, sugerindo diálogo, ação conjunta, etc., isso não significa que os atores que detêm legitimidade para acessar o tribunal adiram à mesma lógica argumentativa, a qual, por sua vez, forçará e forçou respostas do STF, ainda que de difícil

28 Trata-se da apresentação do autuado preso em flagrante delito perante um juiz, permitindo-lhe o contato pessoal em até 24 horas após sua prisão, conforme as discussões travadas no STF na ADI 5.240. 
delimitação temporal, que impactarão nos resultados das medidas cautelares e definitivas deferidas. Trata-se de um problema de consequências inesperadas, quando lembramos que essa deferência recíproca é uma das justificativas para a aplicação do ECI.

Os pedidos da Rcl 23.872/DF, proposta pela Anadep, demonstram como medidas, supostamente, deferentes poderão tornar-se unilateralmente impositivas, uma vez que o efeito da decisão reclamatória é cassar um ato ou obrigar o cumprimento efetivo e imediato para a instituição das audiências de custódia não implantadas dentro do prazo de 90 dias. No mesmo sentido, a Rcl 26.111/DF, proposta pela DPU, tentou determinar medidas estruturais e emergenciais para superar a crise carcerária no Amazonas, exigindo (e não chamando ao debate) do Executivo inúmeras medidas (fechamento do presídio; limite de transferência de presos, inspeções, etc.).

Nenhuma dessas decisões, porém, parece influenciar tanto o futuro do ECI, enquanto doutrina constitucional, como o RE 641.320/RS. O relator, Gilmar Mendes, refratário à tese do ECI, realizou uma leitura da jurisprudência do STF no sentido de sustentar que a Corte acolhe a tipologia das sentenças manipulativas de efeitos aditivos. Tais decisões não apenas seriam capazes de alterar o ordenamento jurídico, mas, também, de inserir consequências estruturais para os órgãos do Judiciário e demais poderes, por meio do que denominou complex enforcement. As sugestões estruturais de Gilmar não vingaram naquele caso, mas colocaram em questão a necessidade da declaração de um ECI para que o STF desenvolva medidas para solucionar graves violações de direitos fundamentais, o que poderá fazê-lo em qualquer classe processual, aparentemente.

Os ministros que votaram naquela assentada não problematizaram a categoria desenvolvida pelo relator, apenas se contrapuseram às suas propostas, muito embora tenham votado no sentido de acolher a tese formulada sobre as medidas alternativas presentes na LEP a respeito da progressão de regime. A tese defendida por Gilmar Mendes, e referendada pelo Pleno, é muito semelhante a alguns pedidos indeferidos na medida cautelar da ADPF 347 (especialmente, $d$, e e f), ou seja, por meio de decisões manipulativas, o tribunal poderá alcançar resultados semelhantes sem decretar o ECI; porém, essa conclusão não é definitiva, tendo em vista o silêncio da Suprema Corte sobre o complex enforcement.

A categoria foi, novamente, utilizada pelo Ministro na Ação Direta de Inconstitucionalidade por Omissão (ADO) 25 (DJe 17/08/2017). Na ocasião, o relator, Gilmar Mendes, voltou a citar o complex enforcement, dessa vez para justificar sua utilização ao eventual descumprimento do prazo de 12 meses estipulado para que o Congresso Nacional editasse a lei complementar reguladora do art. 91 do Ato das Disposições Constitucionais Transitórias (ADCT), que estipula compensações aos estados exportadores, em razão da desoneração dos produtos primários e semielaborados do país ampliada pela Emenda Constitucional (EC) n. 42/2003. Após o escoamento do prazo e enquanto não for editada a Lei Complementar (LC), o STF determinou que caberá ao Tribunal de Contas da União (TCU): a) fixar o valor do montante a ser transferido anualmente aos estados (art. 91, ADCT); e b) calcular 
o valor das quotas a que cada um deles faz jus na linha do acordado no Conselho Nacional de Política Fazendária (Confaz).

Diferentemente do RE 641.320/RS, os ministros, por maioria, vencido Marco Aurélio, concordaram com a estipulação aditiva do relator de repassar a competência para a fixação do montante devido aos estados ao TCU, muito embora nenhum outro voto tenha problematizado a utilização da categoria complex enforcement. Desse modo, permanece a dúvida acerca de seu acolhimento pelo Plenário, mas não restam dúvidas quanto à utilização de decisões estruturais por vias diversas do ECI.

O voto de Marco Aurélio naquela assentada, porém, parece contradizer suas próprias premissas desenvolvidas para o ECI. O Ministro nega, de forma veemente, a possibilidade de fixar prazos para que o Congresso legisle, em razão da ausência de estipulação constitucional expressa. Em seguida, nega a possibilidade de o TCU fazer as vezes de legislador e defende ortodoxia na defesa de princípios constitucionais. Em matéria de omissão constitucional, o Ministro apresentou na ADPF 347 posição heterodoxa ao reconhecer competências para o STF e demais poderes não previstas constitucionalmente, além de deferir medidas cautelares que alteravam o conteúdo do trabalho legislativo. Como justificativa para o monitoramento da decisão de mérito do tribunal, o Ministro terá de impor prazos para a atuação das autoridade requisitadas, portanto, não parece ser possível extrair um posicionamento coeso de Marco Aurélio quanto às omissões constitucionais.

A resposta do Poder Legislativo ao ECI é bastante peculiar: o Senador autor do PL reconheceu que o STF está indo além de seus limites, que a decisão na ADPF impactou e reduziu o poder dos ramos políticos da República, mas a solução foi criar "balizas" à doutrina, em vez de rejeitá-la. A baliza criada inspira-se em categoria empregada pela Corte Constitucional Sul-Africana, o Compromisso Significativo.

A crítica feita a seguir sobre a inserção do Compromisso Significativo não está baseada, em sua essência, em um argumento de tradicional omissão ou inércia do Poder Legislativo em face de decisões do STF em controle de constitucionalidade, mesmo porque há estudos que demonstram o contrário (POGREBINSCHI, 2011), ou na ideia de que o Poder Legislativo não poderia responder ao STF por meio de um PL regulamentando um instituto criado jurisprudencialmente, prática estabelecida em nosso direito, vide a lei que regulamentou o mandado de injunção. O objeto da crítica é a natureza da resposta legislativa.

Caso a proposta legislativa se concretize, o direito constitucional brasileiro será acometido, uma vez mais (SILVA, 2005), pelo sincretismo teórico. Não bastasse o STF importar uma doutrina questionável em seu país de origem, ${ }^{29}$ com premissas teóricas e práticas

29 Além de não ser mais utilizado desde 2004, não é possível afirmar que o ECI surtiu efeitos visíveis e significativos na realidade colombiana. 
não estabelecidas, o legislador fará o mesmo com o Compromisso Significativo ou o engajamento significativo (meaningful engagement). Não fica claro como o Judiciário brasileiro terá de manejar o Compromisso Significativo em um ECI que se viabiliza por meio de um complex enforcement.

Não sugerimos, ao discordar do PL em debate, a impossibilidade de novos desenhos institucionais que tornem as decisões do STF mais permeáveis à interação com os demais poderes, mas o realçamento de apenas dois pontos: a) a inserção da lógica do Compromisso Significativo no meio de uma já confusa delimitação do ECI poderá dificultar o manejo do primeiro pelo STF; e b) aquela medida, da mesma forma que o ECI na Colômbia, não vem colhendo frutos representativos na experiência sul-africana. ${ }^{\mathbf{3 0}}$

Na intenção de reduzir o déficit democrático do ECI, o PL n. 736/2015 propõe que o STF determine a celebração de Compromisso Significativo entre o Poder Público ${ }^{31}$ e o segmento populacional afetado, para que, por meio de intercâmbio, as partes possam celebrar acordo

30 Em seu voto, Marco Aurélio prometeu diálogo com os demais poderes, a imposição de obrigações flexíveis e a retenção do cumprimento das decisões, em uma leitura que pode parecer interessante; contudo, a tese do suposto diálogo entre os poderes não pode ser trazida à baila sem maiores preocupações teóricas e práticas. Infelizmente, por conta da natureza do artigo e do espaço limitado da nota, não poderemos expandir tanto o argumento, mas é importante destacar que o debate sobre diálogos institucionais nos EUA, país cuja produção acadêmica serviu de fonte da tese que subsidiou o voto do ministro (CAMPOS, 2016, p. 244-255), não opera no campo normativo da atividade da Suprema Corte, ou seja, os autores que defendem a metáfora do diálogo, principalmente, Fisher (1988, p. 231-232; 2004, p. VII), Pickerill (2004, p. 11-12) e Whittington (1999) não sugerem que a Suprema Corte deva “ouvir” o Legislativo, ou que eles trabalhem de forma cooperativa, alterando suas tradicionais formas de interação institucional (revisão judicial da lei $>$ resposta do Legislativo $>$ interpretação judicial da resposta legislativa), mas todos destacam, no plano descritivo e explicativo, a ideia de que a construção da interpretação da constitucional (não limitada aos direitos fundamentais) não é feita de forma isolada pela Corte, mas depende das respostas legislativas, que revertem, confirmam ou alteram decisões judiciais com leis que, por conseguinte, estarão sujeitas à revisão judicial posterior. Nenhum deles sugere a inserção de novos procedimentos interativos entre Corte e Parlamento, ou mesmo a extinção do controle de constitucionalidade. No voto da ADPF 347, o ministro caracteriza como diálogo o que ele entende que seja uma espécie de relação interinstitucional (decretação do ECI, decretação de medidas flexíveis aos poderes e posterior monitoramento), mas não explica os ganhos epistemológicos da metáfora para além da aplicação de sua construção norte-americana. Como sustentar "diálogo" quando a Corte é quem diz que o Executivo e o Legislativo são incapazes de solucionar uma violação de direitos fundamentais (sem oportunidade de contraditório), quando a Corte é quem impõe medidas (ainda que flexíveis) que devam ser cumpridas pelos poderes, quando ela mesma decidirá e avaliará as medidas tomadas e, por fim, decidirá quando terminará o ECI? Ou seja, não podemos, de forma apressada, denominar diálogo toda e qualquer interação entre poderes sem algum parâmetro teórico anterior que o defina ou confundir suas dimensões descritivas e normativas.

31 O PL n. 736/2015 refere-se, genericamente, a Poder Público em seu art. 2º (o STF determinará a celebração de compromisso significativo entre o Poder Público e os segmentos populacionais afetados pela ação ou omissão). 
para a formulação e a implementação de programas capazes de afastar a violação de direitos. A sugestão de interações diretas entre a população e o Poder Público é interessante e deveria ser estimulada por muitas e diferentes formas de participação democrática direta na gestão pública, mas não é compreensível por que tal via de participação tenha de ser feita por determinação (esse é o termo do PL n. 736/2015) do Judiciário. Desse modo, uma demanda será judicializada para que possa ser decidida politicamente.

Não fica claro no projeto de lei o ganho democrático em obrigar um acordo pela via judicial, o qual limita o âmbito de transigência política dos agentes e da inovação institucional ao previamente estabelecido nas leis orçamentárias e aos limites tradicionais de atuação política dos poderes, ou seja, o que poderia ser facilmente acordado sem a intermediação do STF. ${ }^{32}$ Seria possível argumentar que o PL pretende garantir que as medidas estruturais determinadas se restrinjam àquelas pactuadas, e não às impostas ao STF, ou que o STF será apenas um mediador, contudo o problema democrático permanece, se a competência de decretação, fiscalização e avaliação do pactuado permanecer no tribunal.

Não obstante o defendido nos dois últimos parágrafos, é bem verdade que os argumentos que envolvem a defesa das formalidades democráticas não são tão fortes e podem ser enfrentados, com significativa veemência e persuasão, ao justificarmos tais medidas como formas de quebrar a inércia política (como ocorre, por exemplo, com a ADI por omissão) ou formas diferenciadas, mas legítimas, de garantir participação de minorias na defesa de direitos fundamentais (função contramajoritária das Cortes). Com efeito, uma forma de complementar, ou tentar salvar o argumento, é demonstrando como a experiência do Compromisso Significativo não está sendo tão bem-sucedida em seu país de origem.

O Engajamento Significativo foi criado pela Corte Constitucional Sul-Africana para lidar, principalmente, com os casos envolvendo o direito à moradia, no qual evicções eram conduzidas pelo governo de forma violenta em áreas de ocupação irregular, e as políticas públicas eram lentas e inefetivas (WILLIAMS, 2014, p. 819-820).

32 Trechos do PL n. 736/2015: "Art. 9-C. O compromisso significativo, de que trata o art. $9^{\circ}$-B, observará as seguintes diretrizes, para que seja considerado válido e eficaz: I - observância ao princípio da independência e harmonia dos Poderes, mediante a preservação de suas competências e prerrogativas constitucional e legalmente fixadas; II - respeito às balizas orçamentárias previstas constitucionalmente e nas leis que estabeleçam o plano plurianual, as diretrizes orçamentárias e os orçamentos anuais; III - respeito às vinculações orçamentárias constitucionalmente fixadas; IV - respeito à destinação legal dos recursos que integram os fundos da administração pública; $\mathrm{V}$ - compatibilidade com as normas de finanças públicas voltadas para a responsabilidade na gestão fiscal, previstas na Lei Complementar n. 101, de 4 de maio de 2000; VI - observância à disponibilidade financeira dos entes federados interessados; VII - respeito à legitimidade dos Chefes do Poder Executivo na definição de prioridades da ação governamental e à sua competência precípua de elaborar e implementar políticas públicas com vistas à concretização dos direitos fundamentais com assento constitucional”. 
A extração dessa determinação judicial possui raízes constitucionais na seção 26 (3) da Constituição do país africano, a qual dispõe que ninguém sofrerá evicção ou terá sua casa demolida sem ordem judicial que tenha levado em consideração todas as circunstâncias relevantes. Sob a interpretação da lei que previne evicções ilegais de 1998 e daquela norma constitucional, a Corte Sul-Africana, concretizando os requisitos legislativos de justiça e equidade, determinou que tais requisitos dependem de discussões apropriadas (proper discussion) e, quando necessário, tentativas de mediação, ou seja, de acordo com a Constituição e leis locais, os ocupantes irregulares possuem um direito de participação no processo de busca de uma justa solução para o problema, construções interpretativas que culminaram no engajamento significativo (LIEBENBERG, 2012, p. 14).

No caso Occupiers of 51 Olivia Rd. v. City of Johannesburg (2008), ${ }^{33}$ a Corte Sul-Africana, dois dias antes da oitiva do recurso, determinou que a cidade e os recorrentes engajassem entre si de forma significativa, na tentativa de resolver suas diferenças à luz dos valores constitucionais e aliviar os problemas dos requerentes, com base no art. 26. Ou seja, o engajamento ocorreu antes da decisão judicial e a Corte estava ciente das possíveis assimetrias de poder na situação de pessoas prestes a perder suas casas em face de uma decisão judicial (WILLIAMS, 2014, p. 829), preocupação inexistente no PL sobre ECI.

O requisito procedimental de que o engajamento significativo ocorra antes da decisão final, é bem verdade, não é tão consistente na jurisprudência da Corte Constitucional (WILLIAMS, 2014, p. 831). Um ano após o caso descrito acima, no julgado Residents of Joe Slovo Community, Western Cape v. Thubelisha Homes (2009), a Corte estabeleceu a necessidade de um engajamento significativo após sua decisão, em razão de ter identificado sérios problemas nos processos de engajamento anteriores à ação (imposto top-down, não estruturado e destituído de mútua compreensão). Para que fosse levado a cabo o requerido pela Corte, foram detalhadas ordens de engajamento, que incluíam uma gama de tópicos que o governo estava obrigado a pôr em consulta de forma efetiva, principalmente sobre a natureza da acomodação alternativa a ser fornecida e que tais acordos seriam monitorados após sua realização (WILLIAMS, 2014, p. 832).

Tal mudança, porém, é criticada pelos estudiosos do tribunal por enfraquecer tal instituto, uma vez que o engajamento significativo não funcionaria mais como um critério para a análise da legitimação da evicção e, ademais, as tratativas de engajamento posteriores à decisão da Corte não surtiram os efeitos esperados pelas partes (LIEBENBERG, 2012, p. 24; RAY, 2011, p. 112).

De acordo com Williams (2014, p. 834), a experiência sul-africana demonstra que, para que tenha o mínimo de funcionalidade, o engajamento significativo deve ser pensado sobre

Mais de 400 ocupantes de dois edifícios no centro da cidade de Joanesburgo apelaram de uma ordem que autorizava seu despejo, porque os edifícios onde residiam eram, supostamente, inseguros. 
os seguintes pontos: 1) a determinação da Corte deve articular em detalhes uma estrutura para o desenvolvimento do procedimento, objetivos específicos ou quesitos que precisam ser enfrentados pelas partes, e um mecanismo de supervisão judicial dos resultados; 2) as medidas devem ser empregadas para solucionar o desequilíbrio de poder, barganha e ação das partes, mas principalmente dos mais marginalizados (assistência jurídica, peritos, etc.); e 3) o engajamento entre os advogados que representam as comunidades deve ser efetivo, para que não ocorram influências negativas na condução judicial do procedimento (conselhos sobre os cursos de ação, estratégia judicial perante a Corte, etc.).

Da mesma forma que o ECI na Colômbia, o Compromisso Significativo ou engajamento significativo não é uma prática estabelecida ou imune à crítica na África do Sul (LIEBENBERG, 2012, p. 26; RAY, 2011, p. 126). Seus defensores, ademais, ao contrário da proposta legislativa brasileira, condicionam sua realização a um período de pré-judicialização da demanda, e não posterior a ela (quando se proíbe ou se determina a evicção) (CHENWI e TISSINGTON, 2010, p. 21). No caso brasileiro, seria uma proposição posterior à declaração do ECI, monopolizada pelo STF.

Tendo em vista que sua função primordial é ouvir as pessoas afetadas, para maior conhecimento de suas necessidades e pactuar soluções conjuntas, um engajamento significativo demanda igualdade na apresentação de demandas, expertise técnica e igual poder de barganha efetivo, o Projeto de Lei (PL), no entanto, não apresenta soluções para tais problemas procedimentais que importarão na alocação de recursos financeiros (peritos, advogados, etc.). Pensamos que, no mínimo, o PL, caso seja alterado, deverá incorporar tais preocupações. De mais a mais, todos esses pontos tornam-se delicados na transposição para a hipótese dos encarcerados, que não dispõem de meios para formar associações civis para representação de seus interesses nesses acordos. ${ }^{34}$

Não estamos defendendo que devemos garantir tal direito de associação aos presos, ${ }^{\mathbf{3 5}}$ apenas pretendemos salientar a artificialidade de importar um conceito jurisprudencial, em

34 A Corte Constitucional Sul-Africana estendeu o conceito para casos de direito à educação (Hoerskool Ermelo/ 2009; Welkom High School/2011 e Rivonia Primary School/2013), outra situação na qual as partes envolvidas (Estado x comunidades atingidas) podem debater por meio de representantes, mais ou menos, institucionalizados. Porém, da mesma forma que nos casos sobre moradia, o engajamento significativo na educação não foi bem-sucedido. Além de as ordens terem sido apresentadas após a decisão, dificultando o desenvolvimento de soluções mais adequadas, alguns desses casos falharam em garantir participação efetiva às partes mais frágeis da demanda (LIEBENBERG, 2017, p. 37).

35 Poderíamos argumentar, por exemplo, que outras associações poderiam participar ativamente em outros casos de ECI, como associações que envolvam a defesa do direito à educação, à saúde ou à moradia. Conforme ressaltado anteriormente, elaboramos outro artigo no qual discutimos as hipóteses de cabimento do ECI para outras situações. Tendo em vista que a resposta ao seguinte questionamento demanda adentrar naquele ponto, tentaremos resumir a tese central do outro trabalho. Nada mais simples do que comprovar 
estágio de maturação, dentro de um contexto relacionado ao direito à moradia (no qual é possível constituir associações civis), para o contexto da crise carcerária. Se a saída for a designação de uma representação externa (MP ou DP, por exemplo), a questão da falta de representatividade dos presos permaneceria: além de vítimas, são vistos pelo Direito brasileiro como objetos incapazes de acessar a Corte (dependem da boa vontade daqueles que detêm a legitimidade para propor ADPF) e, para defender seus direitos e encetar em negociações com os poderes políticos, precisam de intermediários indicados pelo mesmo estado violador de direitos fundamentais para dar voz a seus reclamos.

Por fim, a resposta do Executivo foi editar MPs (posteriormente convertidas em lei) que alteraram o regramento do Funpen, tornando-o mais dinâmico, contudo acrescendo-lhe objetivos novos e destinando seus recursos para áreas de inteligência e segurança pública. O autor da ação (PSOL) requereu a inclusão dos atos normativos como fatores contribuintes para o ECI e afrontosos à medida cautelar da ADPF 347.

A lógica binária da atuação no controle concentrado, que será mais bem desenvolvida na próxima seção, criou uma trajetória específica para a leitura jurídica das ações dos poderes após o conhecimento da ADPF e da declaração do ECI, submetendo qualquer escolha política feita por eles ao questionamento direto no STF, caso não esteja de acordo com as expectativas dos litigantes.

Não obstante reconhecerem a complexidade da situação prisional, os autores da ADPF largaram mão de suas propostas dialógicas, ${ }^{36}$ compreensivas e flexíveis ao exigirem do STF uma resposta na forma binária da constitucionalidade/inconstitucionalidade de uma escolha política emergencial, que poderia ser pensada, por exemplo, como uma regra experimental (GUBLER, 2014, p. 130), ou seja, o Executivo está pensando em formas e vias para solucionar um problema grave e utilizou o recurso institucional, embora temporário, que entendeu cabível (MP) para monitorar suas consequências. Pode não ter sido a melhor escolha ou que

o cumprimento dos três requisitos elencados pelo STF para declarar um ECI total nos casos de saúde, educação, segurança pública, proteção de grupos vulneráveis, direitos de povos tradicionais, etc.: ainda persiste, faticamente, uma violação generalizada desses direitos ocasionada por uma omissão/inércia/incapacidade dos três poderes, e apenas sua ação conjunta poderá saná-la em nosso país. Contudo, o Ministro Marco Aurélio (de acordo com o trecho transcrito no tópico 01) se antecipou à crítica, sustentando que nosso crônico problema sanitário não justificaria a declaração de um ECI: o motivo? A existência de vontade política e sensibilidade social. Ou seja, não obstante a violação da dignidade humana de forma generalizada e os programas sociais, ineficientes, o fato de o direito à saúde figurar como bandeira político-partidária e estar na pauta de preocupações do brasileiro médio tem o condão de afastar os pressupostos de cabimento do ECI, ou seja, ambos são requisitos prejudiciais implícitos. Portanto, sempre poderemos argumentar que nossos crônicos problemas, exatamente aqueles que permitiriam a participação da sociedade civil organizada em associações, nunca serão objeto de um ECI. 
a política falhe em longo prazo, mas os pedidos forçam a Corte a monopolizar e centralizar os papéis de criadora e avaliadora das políticas públicas a serem, daqui por diante, propostas por aditamentos, ADIs ou pela via reclamatória.

Portanto, os impactos produzidos pela ECI, até o presente momento, não são capazes de alterar os problemas estruturais do sistema carcerário, porquanto os poderes apresentaram respostas que seguem a mesma natureza das políticas tradicionalmente desenvolvidas no Brasil, além de inserirem consequências indesejadas decorrentes da via eleita (ADPF em controle concentrado) e seus efeitos (efeito vinculante e reclamação constitucional).

\section{A SEduÇÃo do Direito E dos direitos: PROMOVEndo MUdANÇAS SOCiAis POR MEIO DO ECI}

O ECI e a consequente determinação judicial de medidas aptas a remediar um problema estrutural de uma sociedade que deita raízes em questões políticas, sociais e econômicas são tentativas de criar mudanças sociais por meio de formas jurídicas. Para os fins desta seção, adotaremos uma noção mais restrita de mudança social, ${ }^{37}$ referente à possibilidade de, por meio do ECI capitaneado pelo Judiciário e a partir do padrão de litígio imposto pela ADPF, cambiar-se os problemas do sistema carcerário brasileiro.

O recurso ao direito por parte dos litigantes pode ser explicado pela suposta vantagem que apresenta em detrimento da via política, ineficiente, mais cara (lobby), dependente de mobilização massiva, que utiliza a barganha e o "toma lá, dá cá” (logrolling) como prática decisória e que incentiva o comportamento personalista na obtenção e destinação de recursos públicos (pork barrel) (SILVERSTEIN, 2009, p. 20-29). No entanto, o discurso de princípios, de direitos humanos, das obrigações incontornáveis e imediatas soa mais atraente para a mobilização em direção ao modelo social desejado. O direito é visto como um instrumento, não apenas de mudança social, mas de desenvolvimento na direção positiva querida pelos litigantes, desconsiderando que o direito pode ser, também, instrumento para o aprofundamento da desigualdade e da manutenção do status quo.

O discurso de direitos estruturados de forma absoluta, representando uma ordem objetiva de valores (CAMPOS, 2016, p. 160), capaz de impor expectativas irreais (a linguagem dos direitos estaria apta a solucionar todos os problemas políticos), poderá aprofundar o conflito social ao colocar os diversos titulares de direitos em campos diametralmente opostos, mas com a mesma intensidade de reivindicações, e empobrecer o debate político (GLENDON, 1991, p. 10). Esse último ponto pode ser evidenciado a partir do pedido de emenda à inicial,

Em uma perspectiva mais ampla, seria a garantia, por meio de alterações significativas, da distribuição de bens e recursos àqueles setores sociais que não desfrutam deles, para fins de melhoria em seu bem-estar. 
questionando as MPs do Executivo - os presos terão direito à construção de melhorias estruturais nos presídios com base em recursos de um fundo que não poderá ser destinado a outras funções, ainda que sirvam para concretizar direitos relacionados à segurança pública, direito de todos.

É inegável que o instrumental proposto pelo ECI pretende contornar as críticas oriundas do mito dos direitos, ${ }^{38}$ ao exigir medidas estruturais flexíveis ${ }^{39}$ e monitoramento contínuo, contudo é incerto se tais formulações serão capazes de superar a lacuna que separa as expectativas dos litigantes das mudanças almejadas no decorrer do processo judicial.

Aquela lacuna poderá gerar os seguintes problemas: 1) caso não delegue a obrigação de monitorar a outro órgão, como o CNJ, por exemplo, o STF atrairá para si uma incumbência que talvez não tenha tempo e condições de cumprir, especialmente se o processo de monitoramento depender de constantes manifestações plenárias (homologação de uma política pública proposta, decisões sobre o aumento ou redução do ECI estipulados por indicadores, etc.); 2) o possível (e provável) fracasso na melhoria da situação carcerária ou o descumprimento das medidas flexíveis ensejará a perda da força simbólica das decisões do tribunal e, por consequência, de sua legitimidade, ${ }^{40}$ situação que se agravará à medida que as decisões de monitoramento se acumularem no tempo; e 3) o STF terá de estar preparado para ter de manter o monitoramento indefinidamente (como no caso colombiano), pois não foram estipulados critérios para aferir quando um ECI se encerra, mas também porque qualquer queda nos indicativos de melhora deverá exigir da Corte o retorno ao caso.

Os processos que são desencadeados por esse tipo de litígio nem sempre produzirão os resultados almejados pelos litigantes; pelo contrário, há um grande grau de risco na figura das estritas intervenções judiciais. O grau de sucesso dessa investida não depende apenas de uma

38 Segundo Scheingold (1974, p. 5), o mito dos direitos repousa sobre a presunção de que a litigância pode evocar uma declaração de direitos por parte das Cortes (pensem na provocação do autor para que o STF declarasse um ECI), a qual poderá ser utilizada para concretizar tais direitos e, finalmente, que a concretização equivalha (tantamount) a uma mudança significativa. O autor não nega a importância do direito para a mudança social, mas reforça seu papel acessório (ancillary), e não principal (SCHEINGOLD, 1974, p. 96).

39 A ideia de injunções estruturais e de litígio de interesse público fundamenta o que Campos (2016, p. 252) denomina de ativismo judicial estrutural dialógico. Novamente, as demandas estruturais e o litígio de interesse público são encarados por meio de uma visão otimista, caracterizada pela citação de textos clássicos da década de 1970, pela não indicação de exemplos de seu sucesso no Brasil, pela exaltação de vantagens e benefícios, mas que ignora desenvolvimentos posteriores e, principalmente, as falhas e os limites desse tipo de estratégia judicial (WEAVER, 2004; TRUBEK, 2011).

40 Os custos para a legitimidade do tribunal para concretizar direitos sociais por meio de injunções estruturais são muito altos, especialmente se falharem (LANDAU, 2012, p. 201). 
resposta favorável da Corte, o que parece estar se desenhando no caso da ADPF 347, mas, principalmente, da resposta dos demais atores envolvidos (SILVERSTEIN, 2009, p. 35).

A forma como os juízes articulam, explicam e racionalizam suas escolhas e a forma como as decisões anteriores influenciam, moldam e restringem as decisões judiciais posteriores são claramente diferentes dos padrões, práticas, retóricas, regras internas e incentivos de condução que operam nos ramos políticos eleitos (SILVERSTEIN, 2009, p. 63). Essas diferenças sugerem que, embora a estratégia jurídica dos litigantes por meio do ECI possa ser relativamente bem-sucedida em curto prazo, as decisões judiciais posteriores (como já foi demonstrado) e as formas legais em que se baseiam podem limitar, direcionar, moldar e restringir essas políticas em longo prazo de maneiras bem diferentes daquelas previstas ou estipuladas pelos litigantes, mas, em especial, diversas daquilo que for determinado pelo STF no mérito. ${ }^{41}$

O Direito pode exercer a função de aríete, destruindo barreiras políticas e institucionais e atravancando o desenvolvimento e a estipulação de políticas públicas, mas a construção da mudança depende da ação dos poderes políticos e da mobilização social. O processo decisório judicial é path dependent (DALLARA e VAUCHEZ, 2012, p. 2), o que significa dizer que, caso uma escolha de trajetória se mostre ineficiente no manejo das medidas estipuladas pelo ECI, será muito difícil contorná-la posteriormente. Algumas escolhas e consequências já observadas na prática da Corte podem ilustrar o argumento desenvolvido nos dois últimos parágrafos.

Ao escolher a ADPF, de legitimidade restrita, os litigantes optaram por uma via que exclui a participação da população afetada pelas violações apontadas. Esta continua silente quanto a seus reclamos, impondo uma decisão judicial e a posterior construção de políticas públicas top-down, reforçando o estigma segregador do encarceramento. ${ }^{42}$

Como consequência indesejada, pelos litigantes e pelo STF, da trajetória em curso está o efeito vinculante da ADPF e sua acentuada característica de controle de constitucionalidade e de proteção incidental de direitos fundamentais, ${ }^{43}$ impondo um padrão de fiscalização do cumprimento da medida cautelar focado na reclamação constitucional, que opera segundo a lógica do cumprimento/descumprimento de uma decisão do STF, negando o aspecto dialógico das medidas estruturais.

41 O risco da sedução do direito existe em outros contextos e em outras ações e medidas judiciais, com toda a certeza, contudo em nenhuma delas os riscos serão potencializados quanto à inserção de um ECI. Ademais, seu provável fracasso poderá trazer mais problemas estruturais, além daquele que se pretende solucionar.

42 Campos (2016, p. 260-262) reconhece a deficiência de representatividade na limitada titularidade para a propositura da ADPF, mas, ainda assim, reforça o caráter preferencial de seu manejo.

43 Benvindo e Costa (2014) demonstraram, por meio de estudo empírico, o descompasso entre o discurso retórico da dogmática constitucional dominante, que propaga uma versão idealizada do controle abstrato e concentrado de constitucionalidade, supostamente criado para a proteção dos direitos fundamentais, e a prática burocratizada de racionalização da administração pública e de questões relacionadas aos conflitos federativos. 
A escolha de uma via abstrata e concentrada permitiu ao tribunal fracionar, de forma mais impessoal (com relação ao que pudesse ocorrer no controle difuso), o julgamento de uma de suas mais delicadas construções doutrinárias, a qual identifica, em medida cautelar, violações generalizadas de direitos fundamentais e omissão política estrutural que podem, aparentemente, aguardar o julgamento do mérito, postergado de modo indefinido no tempo.

O reconhecimento do ECI foi uma parcial vitória dos litigantes, mas pode significar uma estratégia equivocada por parte do STF ao sugerir que sua decisão cautelar, em verdade, desempenharia uma função pedagógica ${ }^{44}$ para os demais poderes, forçando a atuação daqueles e diminuindo sua responsabilidade de decidir o mérito em prazo hábil. Dito em outras palavras, o STF decreta uma medida cautelar de cunho pedagógico, para que não tenha de manifestar-se no mérito, na esperança de que os poderes políticos se mobilizem para solucionar o problema. A preocupação apenas com a força simbólica de sua decisão explicaria a gravidade da declaração de falência política do país e a contínua violação de direitos, porém acompanhada de medidas cautelares sem efeitos práticos e demora na imposição das medidas flexíveis, supostamente, capazes de sanar o problema em definitivo.

A declaração do ECI por meio de uma ADPF, igualmente, demonstra uma escolha do STF, que não era estranho ao problema carcerário do país, tendo em vista que recebeu inúmeros pedidos de intervenção federal entre 2003 e 2013 sobre o tema (GARCIA, 2014). As Intervenções Federais (IF) 5.129 e 4.822, por exemplo, repetem exatamente os problemas apontados na inicial da ADPF 347, mas o STF preferiu manter-se silente, o que não ocorreu nos casos de precatórios cobrados pelos credores dos estados, os quais obtiveram decisões rápidas da Corte, ainda que no sentido do indeferimento da intervenção federal. Portanto, no caso dos precatórios, muito embora rejeitadas as IF, o STF se articulou para dar uma resposta ao problema.

Segundo Garcia (2014, p. 82-85), a intervenção federal não é eficaz como forma urgente de proteção da dignidade humana, pois os casos demoram para ser julgados e o STF não se dispôs a travar um diálogo entre as partes envolvidas no caso do superencarceramento, mesmo que por meio do indeferimento do pedido inicial, tal como realizado nos casos sobre dívidas dos estados. ${ }^{45}$

Ainda que não sejam hipóteses capazes de ser confirmadas sem pesquisa empírica, o STF não estaria disposto a arcar com os custos políticos de limitar a autonomia política e

44 Na ADPF 347, a função pedagógica da Corte ao declarar ao ECI foi mencionada pelos Ministros Fachin ("papel do Judiciário [...] possui antes de tudo um caráter simbólico, pedagógico e de reconhecimento da inadequada proteção dos direitos fundamentais"), Fux ("Eu entendo que a Suprema Corte [...] tem que ter um efeito pedagógico”) e Lewandowski (“Trata-se [...] de uma medida pedagógica importante de caráter didático”).

45 Antes que se contra-argumente no sentido de uma maior efetividade do ECI no caso, em função de seu caráter interventivo estruturante em âmbito nacional, e não pontual em um único estado, duas críticas 
administrativa dos estados, com todas as consequências dela decorrentes, e, ademais, a decretação da intervenção federal impediria a mobilidade política do Executivo, pois lhe retiraria a possibilidade de utilizar as emendas constitucionais (art. 60, $\S 1^{\circ}$ ) como mecanismo de concretização de planos de governo (SOUZA, 2005, p. 111).

Não pretendemos adentrar na discussão filosófica acerca da existência, ou não, de uma função a ser desempenhada pelo Direito (garantir a paz, desenvolvimento social, emancipação social, etc.), mas, sim, no tópico político-sociológico acerca da capacidade de o Direito, e mais especificamente de Cortes, mobilizar mudanças sociais, no caso, de mudar o estado de coisas caracterizado como inconstitucional.

Inicialmente, o ECI desenvolve o ideal romântico de que a racionalidade de nosso constitucionalismo aspiracional nunca seja contrariada pela realidade social que enfrenta diariamente (ROMERO PÁEZ, 2012, p. 261). A tentativa de adequar, forçadamente, a dinâmica social de acordo com uma geometria jurídica é um verdadeiro trabalho de Sísifo.

Violações de regras constitucionais ocorrem diariamente, e o substrato para a escolha de um governo pautado por regras jurídicas é, exatamente, estipular padrões de conformações de comportamentos, em detrimento de outras ações possíveis, mas que não ilidem a capacidade de o sistema normativo prever o eventual descumprimento de suas regras (criando sistemas de monitoramento $)^{46}$ e, em especial, o eventual cumprimento gradual de suas obrigações (LIVET, 2009, p. 33).

Como demonstrado pelo STF na ADO 1.968, a obrigação dos poderes políticos é manter-se dentro da obrigação constitucional de empregar meios para erradicar o analfabetismo, porém negar a existência de graus de cumprimento dessa expectativa de câmbio social é irreal - ainda estamos longe do ideal no campo educacional, mas não significa que haja o descumprimento de uma regra constitucional por estarmos tentando. ${ }^{47}$

ainda se mantêm. Em primeiro lugar, como desenvolvido nesta seção, a efetividade do ECI é duvidosa e incerta; trata-se, em verdade, de uma aposta feita pelo STF, que não rendeu frutos na Colômbia no sistema carcerário e tem tido limitado sucesso no caso dos deslocados internos. Ou seja, a IF ou o ECI estariam no mesmo patamar de incerteza quanto ao resultado. Em segundo lugar, trata-se daquilo que o STF considera como violações toleráveis da Constituição - determinar que os estados não paguem dívidas bilionárias em precatórios enseja uma resposta rápida da Corte, que decidiu mais de 30 casos de IF sobre precatórios (GARCIA, 2014, p. 79), mas o STF esperou quase 15 anos para manifestar-se sobre o tema do sistema carcerário, tomando como base uma doutrina estrangeira de eficácia duvidosa.

46 Como sugere Livet (2009, p. 46), a imposição de normas pretende mudar o mundo a partir de comandos oriundos da mente, mas apenas se isso for possível. Não enunciamos normas quando elas já serão satisfeitas na realidade; assim, paradoxalmente, "o enunciado de uma norma pressupõe que ela não seja sempre satisfeita no nosso mundo real".

47 A ADO 1.968 questionava dados do IBGE (1995) que demonstravam a manutenção do analfabetismo no Brasil e alegavam a omissão do Executivo no cumprimento do arts. 6 , 23, V, 208, I, e 214, I. Para declarar 
Partindo dessa premissa, o ECI insere um duplo problema para a dogmática constitucional clássica: a) a realidade da sociedade brasileira nunca poderá estar fora dos padrões das normas constitucionais, não importa quão ideais e utópicas, obscurecendo a relação entre a ideia de Constituição como uma construção representativa da sociedade e uma sociedade ainda inexistente a ser moldada a partir de normas jurídicas constitucionais (ou estamos dentro do cumprimento integral das normas constitucionais, ou estamos em um ECI); e b) se a função dessa Constituição for moldar a sociedade a partir de suas aspirações políticas, não seria justificado supor a atuação de seu defensor (STF) por meio de impactos estruturais apenas nas hipóteses de ECI, mas sim em todo e qualquer descompasso identificado entre a norma e a realidade.

Gerald Rosenberg (1991) sugere que os estudos sobre mudança social por meio do Direito nos EUA superestimam o papel da Suprema Corte. ${ }^{48} \mathrm{O}$ autor não nega que o Direito e as Cortes possam impactar nas estruturas sociais, contudo tais mudanças dependeriam dos seguintes fatores, os quais adaptamos para o caso nacional.

As Cortes poderão produzir reformas sociais efetivas quando outros atores políticos (Executivo e Legislativo, principalmente) oferecerem incentivos positivos para induzir ao cumprimento de suas decisões. Os poderes políticos podem se recusar ou adiar o cumprimento das decisões das Cortes, quando o custo da inércia dos poderes não for grande o suficiente, como parece ser o caso do sistema carcerário brasileiro. A mobilização dos poderes ocorreu após a ADPF 347 (medida provisória e projeto de lei), mas suas respostas foram baseadas no mesmo trajeto de propostas já em curso no país (a MP alterou uma política pública em curso, na figura do Funpen, e o PL visava regulamentar o ECI a partir da lei da ADPF), apenas tangenciando o problema central.

Cortes poderão produzir reforma social efetiva quando outros atores políticos, dispostos a agir, impuserem custos para induzir o cumprimento das determinações judiciais, como via, escusa, justificação ou escudo para sua atuação política. Se uma decisão estrutural da Corte não for "adotada" por

a improcedência da ação, a Ministra Relatora, Cármen Lúcia, afastou a omissão executiva ao justificar a apresentação de um Projeto de Lei (n. 1.258-B), posteriormente convertido na Lei n. 9.394/1996 (Lei de Diretrizes e Bases da Educação Nacional - LDBEN), e a edição da Lei n. 10.172/2001, que estabeleceu o Plano Nacional de Educação, e a política intitulada "Programa Brasil Alfabetizado". A relatora ponderou que "embora não seja o número com o qual o país possa conviver sem a adoção de drásticas medidas para extirpar tão grave mal, dando pleno cumprimento à Constituição, demonstra a atuação do Poder Público na reversão dos dados apresentados [...]”. Após ressaltar o atraso brasileiro em erradicar o analfabetismo, afirmou "que o Brasil tem muitíssimo a fazer em termos de compromisso constitucionalmente imposto de erradicar o analfabetismo, até mesmo para que os direitos fundamentais, a dignidade da pessoa humana, a sua liberdade, a igualdade de oportunidades possam ser efetivados”.

48 Não desconhecemos as críticas feitas ao trabalho de Rosenberg e concordamos com muitas delas. Rosenberg não leva em consideração outros efeitos decorrentes das decisões judiciais e seus impactos complexos na mobilização social. O autor reforça o gap problem da sociologia do Direito, ao estabelecer uma correlação direta entre as expectativas dos litigantes e a resposta da Corte (que pode não os atingir completamente) 
um poder político, criando custos para que os outros ajam para concretizar as medidas impostas, pouco poderá ser feito com as estipulações determinadas pelo STF. Muito embora o ECI pretenda contornar esses problemas, ao envolver, ao mesmo tempo, todos os três poderes, esse poderá ser, outrossim, um dos motivos de seu fracasso.

A centralização da formalização de planos de ação e políticas públicas no e pelo STF enfraquece o poderio político do Executivo e do Legislativo, os quais não terão incentivos suficientes para fornecer, autonomamente, os meios para solucionar os entraves que originaram o ECI. ${ }^{49}$ Isso é algo observado na Colômbia, onde a formulação de medidas específicas para cada um dos poderes não foi suficiente para a criação de políticas públicas melhores, mais eficazes e capazes de encerrar o ECI (RODRÍGUEZ-GARAVITO, 2011, p. 1.695). Ou seja, talvez, obrigar que todos os poderes, ao mesmo tempo, retirem da linguagem política uma ferramenta importante que distancia os poderes políticos do Poder Judiciário.

\section{CONCLUSÃO}

Do ponto de vista dogmático, não é tarefa simples explicar a inserção do ECI no direito constitucional brasileiro. A decisão do STF na ADPF 347 é inconsistente na caracterização dos pressupostos que justificariam a declaração de um ECI, as medidas cautelares deferidas são pouco efetivas, há uma injustificada demora no julgamento do mérito, os poderes apresentaram respostas pouco substantivas e que seguem a mesma natureza das políticas tradicionalmente

para explicar o fracasso do litígio. Contudo, devemos ressaltar que os críticos de Rosenberg, especialmente McCann (1994), focam seus estudos a partir da perspectiva dos litigantes, e não dos instrumentos utilizados pelas Cortes para empreender mudanças sociais, especialmente porque são os interessados que utilizam o Direito como estratégia, e não a Corte que lança mão de experimentos institucionais de eficácia duvidosa para tentar influenciar a sociedade, porque não seria legítimo atribuir à Corte uma agenda de câmbio social específica. O trabalho de Rosenberg tem a vantagem de analisar o problema sob a perspectiva do prometido pelo STF, ou seja, encerrar o ECI por meio de medidas flexíveis, para avaliar se essas medidas terão o condão de empreender mudanças sociais.

49 A amplitude das críticas traz consigo os riscos de uma confusão entre os argumentos que focam, de um lado, nos interesses dos litigantes, ao forçar, legitimamente, o tribunal a adotar decisões que impactem de modo estrutural problemas sociais (litígio estratégico) e, de outro, os argumentos jurídicos/políticos de uma Corte que acolhe pretensões não previstas constitucionalmente ou que influenciem as relações entre poderes. Explica-se: as decisões consideradas de litígio público na experiência norte-americana são, tradicionalmente, as referentes ao aborto, à segregação nas escolas, ao direito dos encarcerados e ao casamento igualitário. Em todos esses casos, a Suprema Corte não criou nenhuma via institucional diferenciada, não manteve planos de monitoramento, não reconheceu um ECI, etc. Porém, da perspectiva dos litigantes, o recurso à Corte fora um exemplo de litígio de interesse público, pela seleção do caso, dos agentes que participaram de seu julgamento, das pessoas envolvidas no caso, do estado ou do ente requerido, a partir da construção jurídica dos argumentos, etc. 
desenvolvidas no Brasil e a capacidade de uma Corte Suprema mudar um estado fático de coisas por meio do Direito é posta em dúvida.

Esta pesquisa poderá ser complementada com a resposta de alguns problemas identificados, mas que não puderam ser mais bem desenvolvidos, em função dos objetivos propostos: 1) Quais serão os impactos para discutir a teoria das omissões inconstitucionais no Brasil com a inserção do ECI, tendo em vista que os problemas estruturais do país não se restringem ao sistema carcerário; 2) Quais deverão ser os indicadores a serem construídos pelo STF quando vier a decidir o mérito do caso, para fins de avaliação de impacto; 3) O ECI é uma medida necessária, tendo em vista a utilização de mecanismos semelhantes pelo STF em outros julgados?; 4) Qual seria a melhor intepretação constitucional de nossa relação entre os três poderes?

O aparente ceticismo das conclusões não pretende defender a manutenção do status quo da população carcerária no Brasil, contudo é necessário abandonarmos o empréstimo constitucional, provavelmente, irrefletido e o otimismo metodológico, para que possamos desenvolver doutrinas mais arrojadas e mais efetivas para a proteção dos direitos fundamentais. O empréstimo constitucional estimula a utilização de doutrinas ou teses gestadas em outros países, cuja eficiência ou eficácia não se comprova com facilidade. O otimismo metodológico, em verdade, esconde o viés de confirmação da tese defendida e é incapaz de fornecer informações aptas a descrever ou explicar o Direito constitucional brasileiro.

A incorporação jurisprudencial de teorias pouco desenvolvidas ou equivocadas (diálogos institucionais, capacidades institucionais, função pedagógica das Cortes, litígio de interesse público, etc.) demonstra uma preocupante confusão entre o papel da ciência do Direito e sua prática, especialmente quando o STF adota uma "teoria" criada para explicar uma realidade constitucional estrangeira para justificar decisões que parecem extrapolar suas competências constitucionais.

Reconhecemos que não oferecemos, neste momento, nenhuma sugestão para a solução do problema trazido pela necessidade de acomodações constitucionais à recepção de inovações institucionais oriundas de decisões do STF. Contudo, as críticas formuladas neste artigo não significam, em si, repreensões a todas e quaisquer experimentações a serem oferecidas pela Corte Suprema, mas intencionam servir de exposição das consequências dessas inovações pela óptica dos demais poderes e, particularmente, dos problemas trazidos por uma inovação em particular, o ECI.

O caminho para a superação do caos carcerário é árduo e demanda respostas rápidas e estruturais, mas, também, rigor e responsabilidade.

\section{AGRADECIMENTOS}

$O$ autor agradece a DiegoWerneck Arguelhes pelos comentários e sugestões, aos dois pareceristas anônimos pelas críticas e sugestões, bem como à equipe da Revista Direito GV. 


\section{REFERÊNCIAS}

ADELLE, Camilla; WEILAND, Sabine. Policy assessment: the state of the art. Impact assessment and project appraisal, v. 30, n. 1, p. 25-33, 2012.

ANDRADE, Bruno Araújo de; TEIXEIRA, Maria Cristina. O estado de coisas inconstitucional - uma análise da ADPF 347. Revista do Curso de Direito da Faculdade de Humanidades e Direito, v. 13, n. 13, p. 85$-121,2016$.

BENVINDO, Juliano Zaiden; COSTA, Alexandre. A quem interessa o controle concentrado de constitucionalidade? O descompasso entre teoria e prática na defesa dos direitos fundamentais, 2014 (Relatório de Pesquisa).

BERNARDI, Renato; MEDA, Ana Paula. Da tripartição de poderes ao estado de coisas inconstitucional e o "compromisso significativo”: a contemporânea atuação do Poder Judiciário na solução de conflitos que envolvem direitos sociais fundamentais. Em tempo, v. 15, p. 11-34, 2016.

BUSTAMANTE, Gabriel. Estado de cosas inconstitucional y políticas públicas. Dissertação (Mestrado em Estudos Políticos) - Pontificia Universidad Javeriana, Bogotá, 2011.

CALDAS, Roberto Correia da Silva Gomes; LASCANE NETO, Felipe. As condições das penitenciárias no Brasil e o estado de coisas inconstitucional. Revista de Direito Penal, Processo Penal e Constituição, v. 2, n. 2, p. 578-600, 2016.

CAMPOS, Carlos Alexandre de Azevedo. Jota mundo: estado de coisas inconstitucional, 2015. Disponível em: http://jota.info/jotamundo-estado-de-coisas-inconstitucional. Acesso em: 3 set. 2017.

CAMPOS, Carlos Alexandre de Azevedo. Estado de coisas inconstitucional. Salvador: Juspodivm, 2016.

CARVAlHO, Gustavo Ferreira de; OlIVEIRA, Fábio de Souza; SANTOS, Júlio Edstron S. O estado de coisas inconstitucional: é possível sua efetivação no Brasil? Revista Acadêmica Conecta FASF, v. 2, n. 1, p. 307-332, 2017.

CASHMORE, Matthew; RICHARDSON, Tim; HILDING-RYEDVIK, Tuija; EMMELIN, Lars. Evaluating the effectiveness of impact assessment instruments: Theorising the nature and implications of their political constitution. Environmental Impact Assessment Review, v. 30, n. 6, p. 371-379, 2010.

CHANCHITPRICHA, Chaunjit; BOND, Alan. Conceptualising the effectiveness of impact assessment processes. Environmental Impact Assessment Review, v. 43, p. 65-72, 2013. 
CHENWI, Lilian;TISSINGTON, Kate. Engaging meaninfully with government on socio-economic rights: a focus on the right to housing. University of the Western Cape/Community Law Centre, p. 4-27, Mar. 2010.

DALLARA, Cristina; VAUCHEZ, Antoine. Courts, social changes and judicial independence. Global Governance Programme, n. 2, p. 1-6, 2012.

DANTAS, Eduardo Sousa. Ações estruturais, direitos fundamentais e o estado de coisas inconstitucional. Revista Constituição e Garantia de Direitos, v. 9, n. 2, p. 155-176, 2016.

DE GIORGI, Raffaele; FARIA, José Eduardo; CAMPILONGO, Celso. Estado de coisas inconstitucional. Estadão, 19 set. 2015. Disponível em: http: / / opiniao.estadao.com.br/estado-de-coisas-inconstitucional, 10000000043. Acesso em: $1^{\circ}$ set. 2017.

DUARTE, Júlia Karolline Vieira; DUARTE NETO, Júlio Gomes. O estado de coisas inconstitucional (ECI): o remédio estrutural para a efetivação dos direitos fundamentais perante um diálogo entre os poderes da União. Revista da ESMAL, n. 1, p. 298-321, 2016.

FISHER, Louis. Constitutional dialogues: interpretation as political process. Princeton: Princeton University Press, 1988.

FISHER, Louis; DEVINS, Neal. The democratic Constitution. New York: Oxford University Press, 2004.

GARCIA, L. S. Reflexões sobre o instituto da intervenção federal e a questão do sistema prisional brasileiro. Aracê: Direitos Humanos em Revista, v. 1, p. 4-207, 2014.

GLENDON, Mary Ann. Rights talk: the impoverishment of political discourse. New York: Free Press, 1991.

GLEZER, Rubens; MACHADO, Eloísa. Decide, mas não muda: STF e o estado de coisas inconstitucional [on-line]. JOTA, 9 set. 2015. Disponível em: https://goo.gl/Xck1iL. Acesso em: 24 set. 2017.

GUBLER, Zachary J. Experimental rules. Boston College Law Review, v. 55, p. 129-179, 2014.

HATHAWAY, Oona A. Path dependence and the law: the course and pattern of legal change in a common law system. Iowa Law Review, v. 86, p. 601-611, 2001.

INSTITUTO BRASILEIRO DE GEOGRAFIA E ESTATÍSTICA (IBGE). Contagem da população 1995. (CD). 
LANDAU, David. The reality of social rights enforcement. Harvard International Law Journal, v. 53, n. 1, p. 401-459, 2012.

LIEBENBERG, Sandra. Remedial principles and meaningful engagement in education rights disputes. Potchefstroom Electronic Law Journal, v. 19, p. 1-43, 2017.

LIEBENBERG, Sandra. Engaging the paradoxes of the universal and particular in human rights adjudication: The possibilities and pitfalls of "meaningful engagement". African Human Rights Law Journal, v. 12, p. 1-29, 2012.

LIVET, Pierre. As normas. Petrópolis: Vozes, 2009.

MAGALHÃES, Breno Baía; SILVA, Sandoval Alves. Quem vê ementa, não vê precedente: ementismo e precedentes judiciais no projeto do novo CPC. In: FREIRE, Alexandre; DANTAS, Bruno; NUNES, Dierle; DIDIER JR., Fredie; MEDINA, José; FUX, Luiz; CAMARGO, Luiz Henrique Volpe; MIRANDA, Pedro (coord.). Novas tendências do processo civil: estudos sobre o projeto do novo Código de Processo Civil. v. 2. Salvador: Juspodivm, 2014. p. 211-238.

MCCANN, M. W. Rights at work. Chicago: UCP, 1994.

MEDA, Ana Paula; BERNARDI, Renato. Direito fundamental à moradia e a sentença T-025/2004 da Corte Constitucional da Colômbia: Estado de Coisas inconstitucional no Brasil. Revista de Direito Sociais e Políticas Públicas, v. 2, n. 1, p. 280-299, 2016.

OLIVEIRA, Vitor Costa. Estado de coisas inconstitucional no direito fundamental à comunicação: análise do regime jurídico da radiodifusão audiovisual no Brasil. 2016. 121 f. Dissertação (Pós-Graduação em Direito) - Universidade Federal de Sergipe, São Cristóvão, 2016.

PENNA, Bernardo Schmidt. Mais do ativismo judicial à brasileira: análise do estado de coisas inconstitucional e da decisão na ADPF 347. Revista Pensamento Jurídico, v. 11, n. 1, p. 9-19, 2017.

PEREIRA, Luciano Meneguetti. O estado de coisas inconstitucional e a violação dos direitos humanos no sistema prisional brasileiro. RIDH, v. 5, n. 1, p. 167-190, 2017.

PICKERILL, J. Mitchell. Constitutional deliberation in Congress: the impact of judicial review in a separated system. Durham: Duke University Press, 2004.

POGREBINSCHI, Thamy. Judicialização ou representação? Política, direito e democracia no Brasil. Rio de Janeiro: Elsevier, 2011. 
RAY, Brian. Proceduralization's triumph and engagement's promise in socio-economic rights litigation. South African Journal on Human Rights, v. 27, p. 107-126, 2011.

RODRIGUEZ, José Rodrigo. Estado de coisas surreal. Disponível em: https: / jota.info/artigos/estadode-coisas-surreal-25092015. Acesso em: 26 set. 2017.

RODRÍGUEZ-GARAVITO, César. Beyond the courtroom: the impact of judicial activism on socioeconomic rights in Latin America. Texas Law Review, n. 89, p. 1.669-1.698, 2011.

RODRÍGUEZ-GARAVITO, César. ¿Cuándo cesa el estado de cosas inconstitucional del desplazamiento? Más allá del desplazamiento, o cómo superar un estado de cosas inconstitucional. In: RODRÍGUEZ-GARAVITO, César (coord.). Más allá del desplazamiento: políticas, derechos y superación del desplazamiento forzado en Colombia. Bogotá: Universidad de los Andes, Facultad de Derecho, Ediciones Uniandes, p. 434-494, 2009. (Colección Estudios Cijus).

ROMERO PÁEZ, Nicolás Augusto. La doctrina del estado de cosas inconstitucional en Colombia: novedades del neoconstitucionalismo y "la inconstitucionalidad de la realidad”. Revista Derecho Público Iberoamericano, n. 1, p. 243-264, 2012.

ROSENBERG, Gerald N. The hollow hope: can courts bring about social change? Chicago: The University of Chicago Press, 1991.

SANTOS, Helena Maria Pereira dos; VIEIRA, José Ribas; DAMASCENO, Luana Regina D’Alessandro; CHAGAS, Tayná Tavares das. Estado de coisas inconstitucional: um estudo sobre os casos colombiano e brasileiro. Quaestio Iuris, v. 8, n. 4, p. 2.596-2.612, 2015.

SCHEINGOLD, Stuart. The politics of rights: lawyers, public policy, and political change. Michigan: YUP, 1974.

SILVA, Virgílio Afonso da. Deciding without deliberating. International Journal of Constitutional Law, v. 11, n. 3, p. 557-584, 2013.

SILVA, Virgílio Afonso da. Direitos fundamentais: conteúdo essencial, restrições e eficácia. São Paulo: Malheiros, 2009.

SILVA, Virgílio Afonso da. Interpretação constitucional e sincretismo metodológico. Interpretação constitucional. São Paulo: Malheiros, 2005, p. 115-143.

SILVERSTEIN, Gordon. Law's allure: how law shapes, constrains, saves, and kills politics. Cambridge: Cambridge University Press, 2009. 
SOUZA, Celina. Federalismo, desenho constitucional e instituições federativas no Brasil pós-1988. Revista de Sociologia e Política, Curitiba, n. 24, p. 105-121, jun. 2005.

STONE SWEET, Alec. Path dependence, precedent, and judicial power. In: SHAPIRO, Martin; STONE SWEET, Alec (eds.). On law, politics \& judicialization. New York: Oxford University Press, p. 112-135, 2002.

STRECK, Lenio Luiz. Estado de coisas inconstitucional é uma nova forma de ativismo [on-line]. Revista Consultor Jurídico, 24 out. 2015. Disponível em: https://goo.gl/ jk0ALM. Acesso em: 24 set. 2017.

TILLER, Emerson H.; CROSS, Frank B. What is legal doctrine? Northwestern University Law Review, v. 100, n. 1, p. 517-533, 2006.

TRUBEK, Louise G. Public interest law: facing the problems of maturity. UALR Law Review, v. 33, n. 4, p. 417-433, 2011.

UPRIMNY, Rodrigo. Judicialization of politics in Colombia: cases, merits and risks. Sur - International Journal on Human Rights, v. 6, p. 49-66, 2007.

WEAVER, Russel L. The rise and decline of structural remedies. San Diego Law Review, v. 41, p. 1.617$-1.632,2004$.

WHITTINGTON, Keith E. Constitutional construction: divided powers and constitutional meaning. Cambridge: Harvard University Press, 1999.

WILLIAMS. Lucy A. The right to housing in South Africa: an evolving jurisprudence. Columbia Human Rights Law Review, v. 45, n. 3, p. 816-845, 2014.

\section{COMO CITAR ESTE ARTIGO:}

MAGALHÃES, Breno Baía. O Estado de Coisas Inconstitucional na ADPF 347 e a sedução do Direito: o impacto da medida cautelar e a resposta dos poderes políticos. Revista Direito GV, v. 15, n. 2, 2019, e1916. doi: http://dx.doi.org/10.1590/23176172201916.
Breno Baía Magalhães Doutor em Direito pela Universidade Federal do Pará (UFPA). Professor de DiREITO CONSTITUCIONAL E INTERnACIONAL DA Universidade Federal do Pará (UFPA). Menção Honrosa no Prêmio CAPES de TeSe 2016. brenobaiamagagmail.com 